\title{
DETERMINATION OF EFFECTIVE CRITICAL FACTORS IN SUCCESSFUL EFFICIENCY MEASUREMENT OF UNIVERSITY DEPARTMENTS BY USING FUZZY DEMATEL METHOD
}

\author{
Turgay TÜRKER* \\ Department of Industrial Engineering, Karabük University, Karabük, Turkey \\ Murat ETÖZ ${ }^{\dagger}$ \\ Department of Business Administration, Mediterrian University, Antalya, Turkey \\ Yasemin ALTUN TÜRKER \\ Department of Industrial Engineering, Karabük University, Karabük, Turkey \\ Received: 22 February 2016 \\ Accepted: 26 May 2016
}

\begin{abstract}
Successful efficiency measurement of university departments is very important issue in today's globalised world and depends on paying high attention on critical input and output factors affecting efficiency measurement. In this study we aim to determine critical input and output factors in efficiency measurement of university departments by using fuzzy DEMATEL (Decision Making Trial and Evaluation Laboratory) method. Factors that are used in efficiency measurement of university departments have been extracted from the literature. Then Fuzzy DEMATEL method has been employed to separate cause and effect group of factors in input and output sets. Cause groups are advised to be used in DEA (Data Envelopment Analysis). This study is the first reference in the literature which uses a fuzzy DEMATEL technique in determination of effective critical input and output factors in successful efficiency measurement of university departments.
\end{abstract}

Keywords: Efficiency measurement, Data envelopment analysis, Fuzzy DEMATEL

\section{ÜNIVERSITELERDE BÖLÜM ETKINLIKLLERININ ÖLÇÜLMESINDE KULLANILAN KRITTIK BAŞARI FAKTÖRLERININ BULANIK DEMATEL YÖNTEMİ İLE BELİRLENMESİ}

\section{Özet}

Günümüzün globalleşen dünyasında üniversite bölümlerinin başarılı etkinlik ölçümü çok önemli bir konudur ve bu ölçümün başarıs1 doğru girdi ve çıktı faktörlerinin belirlenmesine bağlıdır. Bu çalışmada, üniversite bölümlerinin etkinlik ölçümünde kullanılan kritik girdi ve çıktı faktörleri Bulanık DEMATEL (Decision Making Trial and Evaluation Laboratory) yöntemi kullanılarak belirlenmiştir. Öncelikle literatürden üniversite bölümlerinin etkinlik ölçümünde kullanılan faktörler elde edilmiştir. Daha sonra Bulanık DEMATEL yöntemi ile girdi ve çıtı kümeleri için ayrı ayrı etkileyen-etkilenen gruplar belirlenmiştir. Etkileyen grupların VZA'da (Veri Zarflama Analizi) kullanılması önerilmiştir. Bu çalışma üniversite bölümlerinin etkinliklerinin ölçülmesinde kullanılan kritik girdi ve çıktı faktörlerinin tayini için bulanık DEMATEL tekniğinin kullanıldığı literatürdeki ilk çalışmadır.

Anahtar Kelimeler: Etkinlik ölçümü, Veri zarflama analizi, Bulanık DEMATEL

\footnotetext{
* tturker@karabuk.edu.tr (Corresponding author)

$\dagger$ muratetoz@yahoo.co.uk

\$yaseminaltun@karabuk.edu.tr
} 


\section{INTRODUCTION}

Economic crises caused by increase in public sector spending has led to a questioning the concept of public financial management in many countries. Improving the quality of public services, increasing the resource usage capacity, ensuring efficiency, effectiveness and thriftiness in resource usage, make nonprofit government organizations employing efficiency analysis methods in their operations (Eruz, 2005).

Higher education is one of the most important factors in producing information, in high quality servicing to the community and in meeting the qualified work force demand of a country. Transition process to information society began at the last quarter of the twentieth century throughout the world. This process has been continuing since then. Transition process has brought a new global economic structure called knowledge economy. In this new structure, while economic power of individuals is measured with knowledge, education levels and competitiveness of countries is measured with the human and social capital. This process has increased the expectations of public from universities which are primarily responsible for knowledge generation and sharing and has led to increased competition between universities (YÖK, 2007). Besides expectations, the demand for higher education has been continuously increasing in developing countries which have high percentage of young population. While this situation increases the number of universities in developing countries, universities are forced to use their resources effectively. For example, in Turkey, number of universities was 76 in 2003. This number has increased to 190 in 2015. Similarly while enrolments in higher education were about $1,200,000$ in 2003, this number reached to about $6,000,000$ in 2015 . Therefore analysis of effectiveness and efficiency in universities has become a major management tool.

Quality of education is prerequisite for the continuity of competitive advantage of universities. Sustainability of quality depends on efficiency measurements. Efficiency of universities and university departments has been researched from many different points of view by many researches (Ahn, Arnold, Charnes \& Cooper, 1989; Arcelus \& Coleman, 1997; Athanassopoulos \& Shale, 1997; Avkiran, 2001; Breu \& Raab, 1994; Coelli, 1996; Coelli, Rao \& Battese, 1998; El Mahgary \& Lahdelma, 1995; Flegg, Allen, Field \& Thurlow, 2004; Flegg \& Allen, 2007; Friedman \& Sinuany-Stern, 1997; Haksever \& Muragishi,1998; Johnes, 2006; Johnes \& Yu, 2008; Koksal \& Nalcac1, 2006; McMillan \& Datta, 1998; Preeti, Shiv \& Singh, 2009; Worthington \& Lee, 2008). These researches basically strive to get answers to the following questions: Do the inputs used in the system maximize the resulting outputs? Are the types and quantities of inputs and their relevant outputs appropriate to achieve educational goals of universities or university departments? Under current budgetary constraints are academic objectives complied? If the budget cuts are made, to what extent the quality of education to be lowered is allowed? Finding appropriate answers to these questions is the core subject attracted the attention of many researchers. It is clear that academic units' efficiency evaluation is a difficult task due to the difficulties in measurements of inputs and outputs, to the large number of such measures relative to the departments, to the data collection problems, and to the implications of resource allocations as a result of budgetary cuts which are difficult to estimate in advance. Comparing different university departments in terms of efficiency make this problem even more complicated (Arcelus \& Coleman, 1997).

Efficiency is mostly measured by using parametric methods (i.e. ordinary least square method), nonparametric methods (i.e. Data Envelopment Analysis) and performance indicators. These methods have pros and cons comparing to each other. Performance indicators are an effective method when only one input and one output are determined in measuring efficiency. In case of multi input and output, the method doesn't work. In the literature, some of the researches on university efficiency measurement that focus on performance indicators are Cave, Hanney \& Kogan, 1991; Chalmers, 2008; OECD, 2007; Pereira \& Tavares, 2002; Ward, D. 2007. Parametric methods need distribution functions for technology and inefficiency. On the other hand, non-parametric methods use multiple inputs and outputs in efficiency evaluation.

DEA is a nonparametric method which is widely used in measuring the efficiency of organizations. Comparing to other measurement methods, it's advantages is lied on the fact that it uses distance function approach in which multiple inputs and outputs can be employed (Johnes \& $\mathrm{Yu}, 2008)$. There are considerable amount of studies in the literature which use DEA method in efficiency evaluation of universities and university departments (Athanassopoulos \& Shale, 1997; Avkiran, 2001; Coelli, 1996; Flegg, Allen, Field \& Thurlow, 2004; McMillan \& Datta, 1998; Casu \& Thanassoulis, 2006; Fox \& Milbourne, 1999; Salerno, 2006; Stevens, 2001; Worthington, 2001; Glass, McKillop \& Hyndman, 1995; Johnes, 1996).

DEA is a linear programming based technique that aim to evaluate relative performances of decision making units (DMU) in case there exists multiple inputs and outputs which have different measurement units. The 
Basic assumptions of DEA are that all DMUs have similar strategic objectives and they use same kind of inputs and produce same kind of outputs. DEA measures efficiency of DMUs that have same goals and objectives. By using DEA, inefficient DMUs can be determined and corrective measures can be taken. Evaluations of many input and output at the same time are very difficult task for managers. At this point, DEA provides important tool in determination of relative efficiency (Oruc, 2008).

The most important part of DEA is the selection and definition of proper input and output factors. In the literature mostly used inputs in university departments' efficiency evaluation are number of academic staff, number of assist academic staff, number of non-academic staff, number of undergraduate students, number of MSc. students, number of $\mathrm{PhD}$. students, total department expenditures, research budget, department budget, number of laboratories, number of computers, number of classrooms, building usage area, number of courses and minimum score of student selection exam. Outputs are number of papers published in academic journals (SCI, SSCI), number of papers published in peer-reviewed journals, number of proceedings, number of academic researches, number of undergraduate awards, number of postgraduate awards, number of doctorates awards and research Incomes. Numerous numbers of input-output combinations were formed in previous studies (Ahn, Arnold, Charnes \& Cooper, 1989; Arcelus \& Coleman, 1997; Athanassopoulos \& Shale, 1997; Avkiran, 2001; Breu \& Raab, 1994; Flegg, Allen, Field \& Thurlow, 2004; Friedman \& Sinuany-Stern, 1997; Johnes, 2006; Johnes \& Yu, 2008; Koksal \& Nalcac1, 2006; McMillan \& Datta, 1998; Preeti, Shiv \& Singh, 2009; Worthington \& Lee, 2008, Beasley,1990,1995; Bessent, Bessent, Charnes, Cooper \& Thorogood, 1983). Moreover, data availability is the other major concern in formation of input-output factors (Katharaki \& Katharakis, 2010).

However, a systematic method to identify the inputs and outputs hasn't been observed in the literature. Instead, researchers determine these factors intuitively or conceptually. The major drawback in selection of these factors is that researches ignore effects of factors to each other. Factors that are influenced from other factors are not useful in measuring the efficiency of DMUs. Therefore critical factors in efficiency measurement must be determined. Discrimination of factors as cause and effect group is the subject of DEMATEL method. Gabus and Fontela developed DEMATEL method (Gabus \& Fontela, 1972, 1973). This method visualizes the complicated causal relationships of factors via matrices and digraphs. DEMATEL also separates the criteria into cause and effect factors' groups which make decision making easier (Wu \& Lee, 2007).

It is usually difficult to make decision with crisp values in vague environment. Uncertainty in decision making necessitates employment of fuzzy logic. Fuzzy logic usually used to handle uncertainty and vagueness of decision making process (Zadeh, 1965; Bellman \& Zadeh, 1970). DEMATEL method combined with Fuzzy logic is used to obtain more realistic decisions in fuzzy environments. In the literature, there exist some studies that combine DEMATEL and Fuzzy logic (Wu \& Lee, 2007; Mokhtarian,2007; Zhou, Huang \& Zhang, 2011; Chang, Chang \& Wu, 2011).

In this study we aimed to determine critical input and output factors by using fuzzy DEMATEL method for efficiency measurement of university departments. Factors that are used in efficiency measurement of university departments were extracted from the literature. Then Fuzzy DEMATEL method was employed to separate cause and effect group of factors in input and output sets. Cause groups were advised to be used in DEA analysis.

The following sections of the paper are organized as follows. Literature Review about university departments' efficiency measurements and applications of DEMATEL-fuzzy logic combination are presented in section 2. In section 3, applied method is described. In section 4, empirical study is presented. Section 5 is dedicated to discussion about results of the study. Conclusion and further study opportunities are presented in the last section.

\section{LITERATURE REVIEW}

In recent years, considerable amount studies have been done to analyze the efficiency of academic departments in universities. Among these, some important studies are briefly reviewed as follows.

Bessent et al. (1983) used DEA to evaluate the relative efficiency of education programs in a community college in USA. Outputs were considered as revenue from state government, number of students completing the program, and employer satisfaction with training of students. Inputs were student contact hours, number of full time equivalent instructors, square feet of facilities for each program and direct instructional expenditure.

Beasley (1990) studied efficiency of Chemistry and Physics departments in UK. Financial variables (research income and expenditure) were used as inputs. Outputs were numbers of undergraduate and postgraduate students and research ratings. Beasley (1995) also used same data set to determine the research and teaching efficiencies where weight restrictions were applied.

Arcelus and Coleman (1997) assessed short and long term effects of fixed budget formula on the efficiency of academic departments of New Brunswick University by using DEA. Inputs of their model were the number of full time equivalents teaching staffs (professors, instructors etc.), number of support staffs (secretaries, non-faculty student advisors, technicians etc.), operating expenses 
and library expenses. The corresponding outputs were average enrollment per class (student/class), average number of classes taught per department (sections), number of undergraduate students and number of undergraduate students receiving their degree in a given year at any given department, number of graduate students in each departments program receiving their degree in a given year (MSc. and PhD.)

Köksal and Nalçacı (2006) used DEA to measure relative efficiencies of academic departments of an engineering college. They determined input and output criteria utilizing the academic personnel performance measurement of the collage. They also developed measures to compare departments of different disciplines. Their input measures were academic staff salaries (Sum of salaries of faculty and assistants in the department in the period under consideration), potential of the department (20x(average number of publications of a faculty member when appointed as an associate professor, over the past 10 years in the department), Entering students (Weighted sum of students starting BSc. education four years before (1 point), M.Sc. education three years before (3 points) and $\mathrm{PhD}$. education five years before (6 points) than the measurement period).Output measures were research activities and quality (sum of points gathered by the departments academic personnel in that period in publications, editorial work and translation), education activities and quality (Sum of points gathered by the department personnel in that period due to their education activities and their quality), other activities (activities such as administrative duties in the university or other institutions, conference organizations and seminars) and Graduates (Weighted sum of BSc. (1 point), MSc. (3 points) and PhD. (6 points) students graduated in a period).

Preeti et al. (2009) evaluated the performance efficiencies of 19 academic departments of IIT Roorkee (India) through DEA technique. Outputs that they used were the number of academic staff, the number of Nonacademic staff and departmental operating cost. Outputs were total enrolled students, number of postgraduate degrees and number of graduate degrees and research index.

After Gabus and Fontela (1972, 1973) initiated DEMATEL technique, considerable amount of studies have been done concentrated on structural model that gathers group knowledge and visualize the causal relationship of criteria by using graphical diagram. Recently, the DEMATEL and fuzzy DEMATEL methods have been studied in different areas, such as real estate agent service quality (Tseng, 2009), personnel selection (Aksakal \& Dağdeviren, 2010), emergency management (Zhou, Huang, \& Zhang, 2011), supplier selection and evaluation (Chang, Chang, \& Wu, 2011; Büyüközkan \& Çifçi, 2012; Mavi \& Shahabi, 2015), human resources management (Chou, Sun, \& Yen, 2012), machine selection (Organ, 2013), facility layout (Altuntas, Selim, \& Dereli, 2014), private school evaluation (Baykasoglu
\& Durmusoglu, 2014), determining environmental performance (Tsai et al., 2015), project selection (Ortíz, Felizzola, \& Isaza, 2015; Vinodh \& Swarnakar, 2015), ship selection (Sener, 2016).

Aksakal \& Dağdeviren (2010) proposed an integrated algorithm by combined DEMATEL and Analytic Network Process (ANP) for decision making about the personnel selection. There were six evaluation criteria for four candidate personnel. The evaluation criteria were experience, communication, foreign language, computer skills, team member skills, strategic thinking. The analyze results indicated that, communication, team member skills and experience are the crucial criteria in personnel selection, respectively.

Zhou et al. (2011) used fuzzy DEMATEL method to determine influencing critical success factors of emergency management. In this study, a set of 20 complex influencing factors were divided into a cause group and an effect group. According to the analyze results, five factors were defined critical success factors in emergency management.

Chang et al. (2011) studied fuzzy DEMATEL method in determining key factors in supplier selection. Their model analyzed supplier performance to determine influencing critical success factors in supplier selection. In the study, a fuzzy DEMATEL questionnaire was sent to seventeen professional purchasing personnel in the electronic industry. The results showed that technology ability, stable delivery of goods, lead-time and production capability criteria are more influential than other evaluation criteria.

Chou et al. (2012) used an integration of fuzzy Analytic Hierarchy Process (AHP) and fuzzy DEMATEL method in human resource for science and technology (HRST). The fuzzy DEMATEL method was used to capture the complex relationships between dimensions and criteria. It was seen that for HRST, infrastructure is the most important criteria and the education, $R \& D$, expenses and immediate output are more important second-tier criteria than value, cooperation, labor market, human capital and intermediate output.

Organ (2013) used fuzzy DEMATEL method to reveal the relationships among each criteria in machine selection problem for a textile firm. The used criteria were cost, quality, technical properties, performance and flexibility of machines. It was found that, the most important criteria for selection machine in firms is technical properties.

Altuntas et al. (2014) presented a fuzzy DEMATELbased solution approach for facility layout problem. The proposed approach allowed both qualitative and quantitative location factors. They considered six important location factors. These are material flow, information flow, personnel flow, equipment flow, environmental condition and supervision of personnel. To explore the viability of the proposed approach, a real world problem in a machinery industry firm was handled. 
Baykasoglu \& Durmusoglu (2014) used DEMATEL based on ANP and Fuzzy Cognitive Map model for private primary school selection problem. The DEMATEL method was used to determine the relative weight of the main criteria. A case study in Turkey was handled.

Tsai et al. (2015) used to fuzzy DEMATEL to define the direction and level of interaction between environmental performance criteria of the Printed Circuit Board (PCB) industry in Taiwan. The study classified the environmental performance measurement system into 4 major dimensions (i.e., green development, green manufacturing, green management and green recycling), which comprised 10 criteria (i.e., green design, green material procurement, air \& water pollution, waste pollution, energy consumption, green marketing, green transport, green image, green packaging and product recycling). According to the results, it emerged that green design, green material procurement, and energy consumption are the most crucial criteria.

Ortiz et al. (2015) presented both an integrated DEMATEL and ANP technique and only ANP technique to establish the most suitable six sigma project in a public medical center. The hierarchical evaluation model included 3 strategies, 4 criteria and 15 sub-criteria and after analyzing, the integrated method and ANP were compared to evaluate their performance in the decision making process. Because of decreasing error probability, the integrated method could be found better.

Sener (2016) used DEMATEL method to determine ship selection criteria in maritime transportation industry. Real-world data was used to illustrate the application of the model. In this study, ten criteria were used. These were cost, payment due date, delivery time, reputation of the shipping company, flag of the ship, age of the ship, duration of detentions, classification organization, capacity of the ship and speed of the ship. According to the results, reputation of the company was the most important criteria and other critical factors were the duration of detentions, classification organization, cost, and age of the ship.

Although fuzzy DEMATEL method was employed in determination of critical factors in several fields, similar applications weren't encountered on the scope of university department's efficiency measurements. This study aimed to fill this gap in the literature.

\section{Fuzzy DEMATEL Method}

Fuzzy DEMATEL technique includes 7 basic steps;

Step 1: Objectives and Evaluation criteria with respect to them are determined.

Step 2: Decision makers are questioned to determine their judgments about the relationship between criteria. Since human judgments on evaluation criteria include uncertainty, five linguistic terms "Very high influence,
High influence, Low influence, Very low influence, No influence" are determined. Then these linguistic terms are expressed as positive triangular fuzzy numbers as shown in Table 1. The answers of decision makers in terms of linguistic terms are converted to triangular fuzzy numbers.

Table 1. Fuzzy Linguistic Scale

\begin{tabular}{|l|l|}
\hline Linguistic term & Triangular fuzzy number \\
\hline No Influence (No) & $(0,0,0.25)$ \\
\hline Very Low Influence (VL) & $(0,0.25,0.50)$ \\
\hline Low Influence (L) & $(0.25,0.50,0.75)$ \\
\hline High Influence (H) & $(0.5,0.75,1.0)$ \\
\hline Very High Influence (VH) & $(0.75,1.0,1.0)$ \\
\hline
\end{tabular}

Step 3: Let $\tilde{X}^{(k)}$ is the k. evaluators' fuzzy decision matrix about the criteria expressed in terms of fuzzy triangular numbers. $\tilde{X}^{(k)}$ is normalized as follows

$$
\begin{aligned}
\tilde{X}^{(k)} & =\left[\begin{array}{cccc}
0 & \tilde{x}_{12}^{(k)} & \ldots & \tilde{x}_{1 n}^{(k)} \\
\tilde{x}_{21}^{(k)} & 0 & \ldots & \tilde{x}_{2 n}^{(k)} \\
\vdots & \vdots & \ddots & \vdots \\
\tilde{x}_{n 1}^{(k)} & \tilde{x}_{n 2}^{(k)} & \ldots & 0
\end{array}\right], \quad k=1,2, \ldots, p \\
r^{(k)} & =\max _{1 \leq i \leq n}\left(\sum_{j=1}^{n} u_{i j}^{k}\right) \\
\tilde{x}_{i j}^{(k)} & =\frac{\tilde{z}_{i j}^{(k)}}{r^{(k)}}=\left(\frac{l_{i j}^{(k)}}{r^{(k)}}, \frac{m_{i j}^{(k)}}{r^{(k)}}, \frac{u_{i j}^{(k)}}{r^{(k)}}\right)
\end{aligned}
$$

Step 4: In this step, average value of $\mathrm{p}$ evaluators' normalized fuzzy decision matrix is found.

$$
\begin{aligned}
\tilde{X} & =\frac{\tilde{X}^{(1)} \oplus \tilde{X}^{(2)} \oplus \ldots \oplus \tilde{X}^{(p)}}{p} \\
\tilde{X} & =\left[\begin{array}{cccc}
\tilde{x}_{11} & \tilde{x}_{12} & \ldots & \tilde{x}_{1 n} \\
\tilde{x}_{21} & \tilde{x}_{22} & \ldots & \tilde{x}_{2 n} \\
\vdots & \vdots & \ddots & \vdots \\
\tilde{x}_{n 1} & \tilde{x}_{n 2} & \ldots & \tilde{x}_{n n}
\end{array}\right] ; \quad \tilde{x}_{i j}=\frac{\sum_{k=1}^{p} \tilde{x}_{i j}^{(k)}}{p}
\end{aligned}
$$

Step 5: After finding initial direct relation matrix and normalizing it, Total relation fuzzy matrix $(\tilde{T})$ is defined as follows;

$$
\tilde{T}=\tilde{X} \cdot(I-\tilde{X})^{-1}
$$


Step 6: In this step $\tilde{D}_{\tilde{R}}$ and $\tilde{R}_{i}$ are calculated. $\tilde{D}_{i}$ is the sum of the row and $\widetilde{R}_{i}$ is the sum of the column of $\tilde{T}$. Then $\tilde{D}_{i}$ and $\tilde{R}_{i}$ are defuzzified separately.

Best Nonfuzzy Performance (BNP) value (Hsieh et al., 2004) was used as a defuzzification procedure. The BNP value can be found using the following equation;

$$
B N P_{i j}=\left(\left(U_{i j}-L_{i j}\right)+\left(M_{i j}-L_{i j}\right)\right) / 3+L_{i j}
$$

$B N P_{i j}$ represents the defuzzified value of $\tilde{D}_{i}$ and $\tilde{R}_{i}$ . We call defuzzified value of $\tilde{D}_{i}$ and $\tilde{R}_{i}$ as $\mathrm{D}_{\mathrm{i}}$ and $\mathrm{R}_{\mathrm{i}}$ respectively.

In order to determine causal relationships between Critical success factors, $D_{i}+R_{i}$ and $D_{i}-R_{i}$ are calculated. While $D_{i}+R_{i}$ represents degree of central role (how much importance the criteria has), $D_{i}-R_{i}$ shows the degree of relation. Relation divide the criteria in to cause and effect group. If $D_{i}-R_{i}$ is positive then criteria belong to cause group. If $D_{i}-R_{i}$ is negative then criteria belong to effect group.

Step 7: Causal diagram is constructed. In this diagram the horizontal axis represents $D_{i}-R_{i}$ while vertical axis represents $D_{i}+R_{i}$. In this diagram, Criteria above the horizontal axis mean that they belong to cause group. Criteria below the horizontal axis mean that they belong to effect group.

\section{Empirical Study}

In our empirical study, critical input and output factors were distinguished from input and output sets that are used in efficiency measurement of university departments by employing fuzzy DEMATEL method. Factors that are used in efficiency measurement of university departments were extracted from the literature.

According to our objective of determining critical factors in input and output sets, 15 input factors and 8 output factors were selected. Selected inputs and outputs are shown in Table 2 and Table 3, respectively.

Table 2. Selected Input Factors

\begin{tabular}{|l|l|}
\hline Factor & Description \\
\hline $\mathbf{C}_{\text {in }} \mathbf{1}$ & Number of Academic Staff \\
\hline $\mathbf{C}_{\text {in }} \mathbf{2}$ & Number of Assist Academic Staff \\
\hline $\mathbf{C}_{\mathbf{i n}} \mathbf{3}$ & Number of non-Academic Staff \\
\hline $\mathbf{C}_{\mathrm{in}} \mathbf{4}$ & Number of Undergraduate Students \\
\hline $\mathbf{C}_{\mathbf{i n}} \mathbf{5}$ & Number of MSc. Students \\
\hline $\mathbf{C}_{\mathrm{in}} \mathbf{6}$ & Number of PhD. Students \\
\hline $\mathbf{C}_{\mathbf{i n}} \mathbf{7}$ & Total Department Expenditures \\
\hline $\mathbf{C}_{\mathbf{i n}} \mathbf{8}$ & Research Budget \\
\hline $\mathbf{C}_{\mathrm{in}} \mathbf{9}$ & Department Budget \\
\hline
\end{tabular}

\begin{tabular}{|l|l|}
\hline $\mathbf{C}_{\mathbf{i n}} \mathbf{1 0}$ & Number of Laboratories \\
\hline $\mathbf{C}_{\mathbf{i n}} \mathbf{1 1}$ & Number of Computers \\
\hline $\mathbf{C}_{\mathbf{i n}} \mathbf{1 2}$ & Number of Classrooms \\
\hline $\mathbf{C}_{\mathbf{i n}} \mathbf{1 3}$ & Number of Square Meters of Building \\
\hline $\mathbf{C}_{\mathbf{i n}} \mathbf{1 4}$ & Number of Course \\
\hline $\mathbf{C}_{\mathbf{i n}} \mathbf{1 5}$ & Minimum Score of Student Selection Exam \\
\hline
\end{tabular}

Table 3. Selected Output Factors

\begin{tabular}{|l|l|}
\hline Factor & Description \\
\hline $\mathbf{C}_{\text {out }} \mathbf{1}$ & $\begin{array}{l}\text { Number of Papers Published in Academic Journals (SCI, } \\
\text { SSCI) }\end{array}$ \\
\hline $\mathbf{C}_{\text {out }} \mathbf{2}$ & Number of Papers Published in Peer-reviewed Journals \\
\hline $\mathbf{C}_{\text {out }} \mathbf{3}$ & Number of Proceedings \\
\hline $\mathbf{C}_{\text {out }} \mathbf{4}$ & Number of Academic Researches \\
\hline $\mathbf{C}_{\text {out }} \mathbf{5}$ & Number of Undergraduate Awards \\
\hline $\mathbf{C}_{\text {out }} \mathbf{6}$ & Number of Postgraduate Awards \\
\hline $\mathbf{C}_{\text {out }} \mathbf{7}$ & Number of Doctorates Awards \\
\hline $\mathbf{C}_{\text {out }} \mathbf{8}$ & Research Incomes \\
\hline
\end{tabular}

Then questionnaire form was designed for taking opinions of experts who took active roles in academic departments. Experts were chosen from different universities and from different departments as much as possible. Under these circumstances, 8 experts were asked to make pair wise comparisons between each pair of critical input and output factors separately. Experts identified their opinions through linguistic scale determined in Table 1. As an example, the assessment data of an expert for input and output factors are shown in Table 4 and Table 5. 
Table 4. Assessment Data of an Expert for Input Factors in Linguistic Scale

\begin{tabular}{|c|c|c|c|c|c|c|c|c|c|c|c|c|c|c|c|}
\hline & Cin1 & Cin2 & Cin3 & Cin4 & Cin5 & Cin6 & Cin7 & Cin8 & Cin9 & Cin10 & Cin11 & Cin12 & Cin13 & Cin14 & Cin15 \\
\hline Cin1 & - & $\mathrm{H}$ & $\mathrm{L}$ & $\mathrm{L}$ & $\mathrm{L}$ & $\mathrm{L}$ & $\mathrm{L}$ & $\mathrm{L}$ & $\mathrm{L}$ & No & VL & No & VL & VH & VL \\
\hline Cin2 & No & - & $\mathrm{L}$ & VL & $\mathrm{L}$ & $\mathrm{L}$ & VL & VL & VL & No & No & No & VL & No & No \\
\hline Cin 3 & No & No & - & No & No & No & $\mathrm{L}$ & No & $\mathrm{L}$ & No & No & No & $\mathrm{L}$ & No & No \\
\hline Cin4 & $\mathrm{VH}$ & $\mathrm{VH}$ & $\mathrm{H}$ & - & $\mathrm{H}$ & $\mathrm{H}$ & $\mathrm{H}$ & $\mathrm{L}$ & $\mathrm{VH}$ & $\mathrm{VH}$ & VH & $\mathrm{VH}$ & $\mathrm{VH}$ & $\mathrm{H}$ & $\mathrm{L}$ \\
\hline Cin5 & VH & $\mathrm{H}$ & $\mathrm{H}$ & No & - & VH & $\mathrm{H}$ & $\mathrm{H}$ & $\mathrm{H}$ & $\mathrm{H}$ & $\mathrm{H}$ & $\mathrm{H}$ & $\mathrm{H}$ & VH & No \\
\hline Cin6 & $\mathrm{H}$ & $\mathrm{L}$ & $\mathrm{L}$ & VL & VL & - & $\mathrm{L}$ & $\mathrm{H}$ & $\mathrm{H}$ & $\mathrm{H}$ & $\mathrm{H}$ & $\mathrm{H}$ & $\mathrm{H}$ & $\mathrm{H}$ & No \\
\hline Cin7 & $\mathrm{H}$ & $\mathrm{H}$ & No & $\mathrm{H}$ & $\mathrm{H}$ & $\mathrm{H}$ & - & $\mathrm{H}$ & $\mathrm{H}$ & $\mathrm{H}$ & $\mathrm{H}$ & $\mathrm{H}$ & $\mathrm{H}$ & No & VL \\
\hline Cin8 & $\mathrm{H}$ & $\mathrm{H}$ & No & No & $\mathrm{H}$ & $\mathrm{H}$ & $\mathrm{VH}$ & - & $\mathrm{VH}$ & $\mathrm{H}$ & $\mathrm{H}$ & VL & No & No & No \\
\hline Cin9 & $\mathrm{H}$ & $\mathrm{H}$ & $\mathrm{H}$ & $\mathrm{H}$ & $\mathrm{H}$ & $\mathrm{H}$ & VH & VH & - & $\mathrm{VH}$ & $\mathrm{H}$ & $\mathrm{H}$ & $\mathrm{H}$ & $\mathrm{L}$ & $\mathrm{VH}$ \\
\hline Cin10 & $\mathrm{L}$ & $\mathrm{L}$ & No & $\mathrm{H}$ & $\mathrm{H}$ & $\mathrm{H}$ & VH & VH & $\mathrm{VH}$ & - & VL & VL & $\mathrm{H}$ & $\mathrm{H}$ & $\mathrm{H}$ \\
\hline Cin11 & No & No & No & $\mathrm{H}$ & $\mathrm{H}$ & $\mathrm{H}$ & $\mathrm{H}$ & No & VH & $\mathrm{L}$ & - & $\mathrm{L}$ & $\mathrm{H}$ & $\mathrm{H}$ & $\mathrm{L}$ \\
\hline Cin12 & No & No & No & VL & VL & VL & $\mathrm{L}$ & No & $\mathrm{L}$ & No & No & - & $\mathrm{H}$ & No & No \\
\hline Cin13 & No & No & No & $\mathrm{H}$ & $\mathrm{H}$ & $\mathrm{H}$ & VL & No & $\mathrm{L}$ & VL & VL & $\mathrm{L}$ & - & No & No \\
\hline Cin14 & $\mathrm{H}$ & $\mathrm{L}$ & No & No & No & No & $\mathrm{L}$ & No & $\mathrm{L}$ & $\mathrm{L}$ & $\mathrm{L}$ & $\mathrm{H}$ & VL & - & $\mathrm{L}$ \\
\hline Cin15 & VL & VL & No & VL & No & No & No & No & No & No & No & No & No & No & - \\
\hline
\end{tabular}

Table 5. Assessment Data of an Expert for Output Factors in Linguistic Scale

\begin{tabular}{lllllllll}
\hline & $\mathrm{C}_{\text {out }} 1$ & $\mathrm{C}_{\text {out }} 2$ & $\mathrm{C}_{\text {out }} 3$ & $\mathrm{C}_{\text {out }} 4$ & $\mathrm{C}_{\text {out }} 5$ & $\mathrm{C}_{\text {out }} 6$ & $\mathrm{C}_{\text {out }} 7$ & $\mathrm{C}_{\text {out }} 8$ \\
\hline $\mathrm{C}_{\text {out }} 1$ & - & $\mathrm{VH}$ & $\mathrm{H}$ & $\mathrm{L}$ & $\mathrm{No}$ & $\mathrm{No}$ & $\mathrm{No}$ & $\mathrm{VL}$ \\
$\mathrm{C}_{\text {out }} 2$ & $\mathrm{H}$ & - & $\mathrm{L}$ & $\mathrm{H}$ & $\mathrm{No}$ & $\mathrm{VL}$ & $\mathrm{No}$ & No \\
$\mathrm{C}_{\text {out }} 3$ & $\mathrm{~L}$ & $\mathrm{VL}$ & - & $\mathrm{No}$ & $\mathrm{No}$ & $\mathrm{No}$ & $\mathrm{No}$ & No \\
$\mathrm{C}_{\text {out }} 4$ & $\mathrm{H}$ & $\mathrm{H}$ & $\mathrm{VH}$ & - & $\mathrm{VL}$ & $\mathrm{H}$ & $\mathrm{H}$ & $\mathrm{VH}$ \\
$\mathrm{C}_{\text {out }} 5$ & $\mathrm{~L}$ & $\mathrm{VL}$ & $\mathrm{L}$ & $\mathrm{L}$ & - & $\mathrm{VH}$ & $\mathrm{H}$ & $\mathrm{VL}$ \\
$\mathrm{C}_{\text {out }} 6$ & $\mathrm{H}$ & $\mathrm{H}$ & $\mathrm{VH}$ & $\mathrm{H}$ & $\mathrm{No}$ & - & $\mathrm{VH}$ & $\mathrm{H}$ \\
$\mathrm{C}_{\text {out }} 7$ & $\mathrm{H}$ & $\mathrm{VH}$ & $\mathrm{H}$ & $\mathrm{L}$ & $\mathrm{No}$ & $\mathrm{No}$ & - & $\mathrm{H}$ \\
$\mathrm{C}_{\text {out }} 8$ & $\mathrm{VL}$ & $\mathrm{L}$ & $\mathrm{VL}$ & $\mathrm{H}$ & $\mathrm{L}$ & $\mathrm{VL}$ & $\mathrm{VL}$ & -
\end{tabular}

Assessment data of each expert in linguistic scale were then converted to triangular fuzzy numbers by using conversion rules given in Table 1. As an example, assessment data of an expert given in Table 4 and Table 5 are redefined as triangular fuzzy numbers in Table 1 and Table 2 in the Appendix. $\mathrm{C} 1$ through $\mathrm{C} 15$ are critical input factors, $\mathrm{C} 1$ through $\mathrm{C} 8$ are critical output factors and $l, m, u$ are the lower, medium and upper limit of triangular fuzzy numbers respectively.

Totally 16 assessment matrices ( 8 for input factors and 8 for output factors) were obtained from experts. Each matrix (also called as initial direct relation matrix) was then normalized by using Eq. (2) and Eq. (3). Then normalized direct relation matrices were obtained by getting average of 8 normalized direct relation matrices by using Eq. (4) for input and output factors separately. Normalized direct relation matrices are shown in Table 3 and Table 4 in the Appendix.

Next, Total relation matrices (Table 5 and Table 6 in the Appendix) were obtained by using Eq. (6). $\tilde{D}_{i \sim}$ and $\widetilde{R}_{i}$ were calculated. $\tilde{D}_{i}$ is the sum of the row and $\tilde{R}_{i}$ is the sum of the column of $\tilde{T}$. Then $\tilde{D}_{i}$ and $\tilde{R}_{i}$ were defuzzified separately by using Eq. (7). Then, $\mathrm{D}_{\mathrm{i}}+\mathrm{R}_{\mathrm{i}}$ and $\mathrm{D}_{\mathrm{i}}-\mathrm{R}_{\mathrm{i}}$ were calculated. The values of $\tilde{D}_{i}, \widetilde{R}_{i}, D_{i}, R_{i}$, $D_{i}+R_{i}$ and $D_{i}-R_{i}$ are shown in Table 6 for inputs and Table 7 for outputs.

Table 6. Values of $\tilde{D}_{i}, \tilde{R}_{i}, D_{i}, R_{i}, D_{i}+R_{i}$ and $D_{i}-R_{i}$ for Input Factors

\begin{tabular}{|c|c|c|c|c|c|c|c|c|c|c|}
\hline \multirow{2}{*}{ Factor } & \multicolumn{3}{|c|}{$\tilde{D}_{i}$} & \multicolumn{3}{|c|}{$\tilde{R}_{i}$} & \multirow{2}{*}{$D$} & \multirow{2}{*}{$\boldsymbol{R}$} & \multirow{2}{*}{$D+R$} & \multirow{2}{*}{$D-R$} \\
\hline & $l$ & $m$ & $u$ & $l$ & $m$ & $u$ & & & & \\
\hline 1 & 0.5643 & 1.1711 & 2.8896 & 0.3913 & 0.8478 & 2.3079 & 1.1655 & 0.9215 & 2.0870 & 0.2440 \\
\hline 2 & 0.1611 & 0.5145 & 1.7764 & 0.4155 & 0.9106 & 2.3576 & 0.7099 & 0.9509 & 1.6608 & -0.2410 \\
\hline 3 & 0.0836 & 0.2319 & 1.2905 & 0.2605 & 0.5703 & 1.8835 & 0.4796 & 0.7311 & 1.2107 & -0.2515 \\
\hline 4 & 0.8292 & 1.5889 & 3.2657 & 0.3222 & 0.7974 & 2.2681 & 1.3418 & 0.9144 & 2.2562 & 0.4274 \\
\hline 5 & 0.5350 & 1.1361 & 2.8835 & 0.3964 & 0.9349 & 2.5081 & 1.1615 & 1.0156 & 2.1771 & 0.1460 \\
\hline 6 & 0.4811 & 1.1071 & 2.8242 & 0.4471 & 1.0040 & 2.6312 & 1.1500 & 1.0627 & 2.2127 & 0.0873 \\
\hline
\end{tabular}




\begin{tabular}{|c|c|c|c|c|c|c|c|c|c|c|}
\hline $\mathbf{7}$ & 0.6040 & 1.2490 & 3.0614 & 0.5175 & 1.1457 & 2.6987 & 1.2355 & 1.1090 & 2.3445 & 0.1265 \\
\hline $\mathbf{8}$ & 0.4994 & 1.0265 & 2.5361 & 0.4257 & 0.8734 & 2.2721 & 1.0211 & 0.9066 & 1.9276 & 0.1145 \\
\hline $\mathbf{9}$ & 0.7635 & 1.4997 & 3.3117 & 0.6128 & 1.2739 & 2.9402 & 1.3493 & 1.2005 & 2.5498 & 0.1488 \\
\hline $\mathbf{1 0}$ & 0.6160 & 1.2933 & 2.9335 & 0.4449 & 0.9319 & 2.3844 & 1.2036 & 0.9572 & 2.1608 & 0.2464 \\
\hline $\mathbf{1 1}$ & 0.3249 & 0.8037 & 2.2827 & 0.3903 & 0.8898 & 2.3819 & 0.9205 & 0.9605 & 1.8810 & -0.0399 \\
\hline $\mathbf{1 2}$ & 0.1059 & 0.3858 & 1.5574 & 0.3640 & 0.8571 & 2.3285 & 0.6124 & 0.9405 & 1.5530 & -0.3281 \\
\hline $\mathbf{1 3}$ & 0.2284 & 0.6293 & 1.9734 & 0.4903 & 1.0858 & 2.7286 & 0.7915 & 1.1080 & 1.8995 & -0.3166 \\
\hline $\mathbf{1 4}$ & 0.2045 & 0.5812 & 1.9073 & 0.3092 & 0.6705 & 2.0628 & 0.7613 & 0.8080 & 1.5694 & -0.0467 \\
\hline $\mathbf{1 5}$ & 0.0000 & 0.1141 & 1.0805 & 0.2134 & 0.5391 & 1.8201 & 0.3982 & 0.7153 & 1.1134 & -0.3171 \\
\hline
\end{tabular}

Table 7. Values of $\tilde{D}_{i}, \tilde{R}_{i}, D_{i}, R_{i}, D_{i}+R_{i}$ and $D_{i}-R_{i}$ for Output Factors

\begin{tabular}{|c|c|c|c|c|c|c|c|c|c|c|}
\hline \multirow{2}{*}{ Factor } & \multicolumn{3}{|c|}{$\tilde{D}_{i}$} & \multicolumn{3}{|c|}{$\tilde{R}_{i}$} & \multirow{2}{*}{$D$} & \multirow{2}{*}{$R$} & \multirow{2}{*}{$D+R$} & \multirow{2}{*}{$D-R$} \\
\hline & $l$ & $m$ & $u$ & $l$ & $m$ & $u$ & & & & \\
\hline 1 & 0.3695 & 0.7674 & 2.4300 & 0.5585 & 1.2677 & 3.1778 & 0.9426 & 1.2957 & 2.2383 & -0.3530 \\
\hline 2 & 0.2774 & 0.5798 & 2.0919 & 0.6163 & 1.3487 & 3.3219 & 0.7981 & 1.3514 & 2.1496 & -0.5533 \\
\hline 3 & 0.1018 & 0.2575 & 1.5375 & 0.6761 & 1.4326 & 3.4709 & 0.5644 & 1.4091 & 1.9735 & -0.8447 \\
\hline 4 & 0.8197 & 1.5895 & 3.5137 & 0.6570 & 1.3080 & 3.2704 & 1.4278 & 1.3071 & 2.7350 & 0.1207 \\
\hline 5 & 0.6321 & 1.3712 & 3.2315 & 0.0000 & 0.1656 & 1.3496 & 1.3236 & 0.5050 & 1.8286 & 0.8185 \\
\hline 6 & 0.6970 & 1.3561 & 3.3727 & 0.2428 & 0.5225 & 1.9269 & 1.3439 & 0.7355 & 2.0794 & 0.6084 \\
\hline 7 & 0.5214 & 1.0419 & 2.9354 & 0.3863 & 0.7567 & 2.2522 & 1.1520 & 0.8742 & 2.0262 & 0.2778 \\
\hline 8 & 0.2100 & 0.8358 & 2.3559 & 0.4918 & 0.9975 & 2.6990 & 0.9939 & 1.0682 & 2.0621 & -0.0743 \\
\hline
\end{tabular}

Next, the causal diagrams (Figure 1 and Figure 2) were constructed by mapping a dataset of $(D+R, D-R)$.

Figure 1. The Causal Diagram of Input Factors

\section{Inputs}

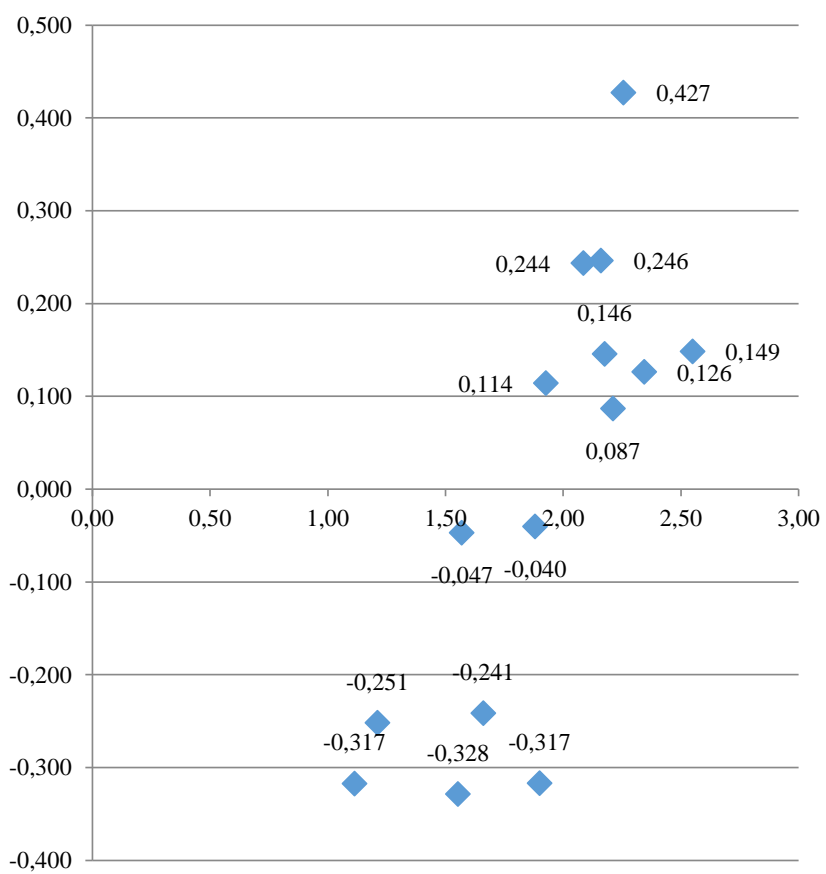

Figure 2. The Causal Diagram of Output Factors

\section{Outputs}

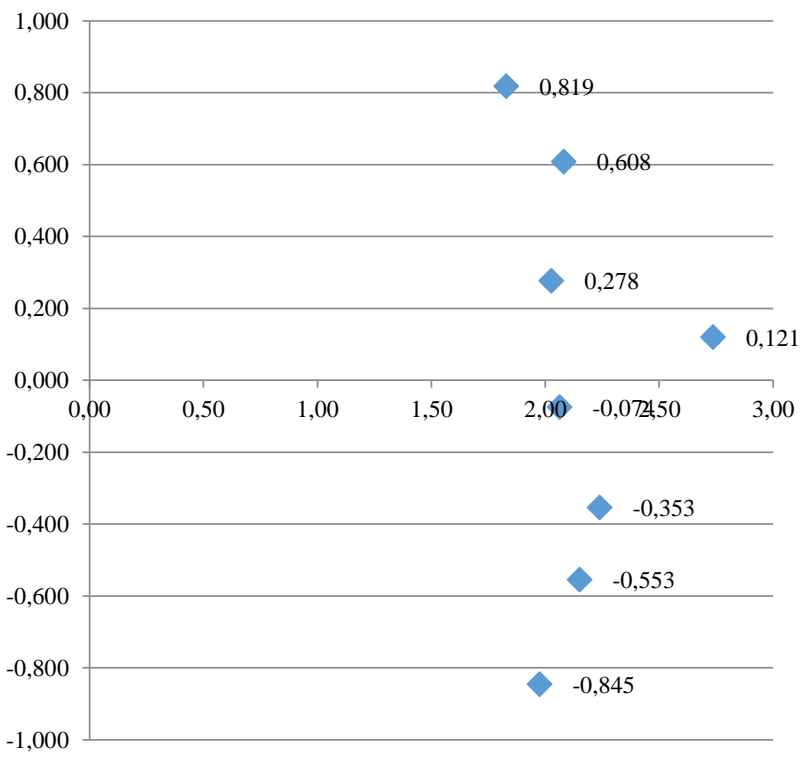

When we look at the causal diagram of input factors (Figure 1), it is easily seen that 8 critical input factors out of 15 belong to cause group. These factors are $\mathrm{C}_{\mathrm{in}} 1$ (Number of Academic Staff), $\mathrm{C}_{\mathrm{in}} 4$ (Number of Undergraduate Students), $\mathrm{C}_{\mathrm{in}} 5$ (Number of MSc. 
Students), $\mathrm{C}_{\mathrm{in}} 6$ (Number of PhD. Students), $\mathrm{C}_{\text {in }} 7$ (Total Department Expenditures), $\mathrm{C}_{\mathrm{in}} 8$ (Research Budget), $\mathrm{C}_{\text {in }} 9$ (Department Budget) and $\mathrm{C}_{\text {in }} 10$ (Number of Laboratories). All other factors belong to effect group.

From Figure 2, it is observed that 4 critical output factors out of 8 belong to cause group. These factors are $\mathrm{C}_{\text {out }} 4$ (Number of Papers Published in Academic Journals (SCI, SSCI)), $\mathrm{C}_{\text {out }} 5$ (Number of Undergraduate Awards), $\mathrm{C}_{\text {out }} 6$ (Number of Postgraduate Awards) and $\mathrm{C}_{\text {out }} 7$ (Number of Doctorates Awards). All other factors belong to effect group.

\section{Discussions}

In this empirical study, the case university departments' efficiency measurements factors are examined through 15 critical input and 8 output factors. According to evaluation results, several implications about efficiency measurement factors can be derived as follows;

Causal diagrams serve us valuable information about effective critical input and output factors in efficiency measurement of university departments. If it is desired to obtain high efficiency in effect group of critical factors, a great deal of attention must be paid to cause group of critical factors. While cause group factors are influencing factors, effect group factors are influenced factors. If we look at the cause and effect relationships in input set, it is clearly seen that number of academic staff, undergraduate students, MSc. students, PhD. students, laboratories, total departments expenditures, research budget and department budget lead to effective efficiency measurement as critical inputs. Similarly, number of academic researches, undergraduate awards, postgraduate awards and doctorates awards are the most important critical outputs for efficiency measurement.

Contrary to common sense, number of papers published in academic journals (SCI, SSCI, peer-

\section{References}

Ahn, T., Arnold, V., Charnes, A., \& Cooper, W.W. (1989). DEA and ratio efficiency analyses for public institutions of higher learning in Texas. Research in Governmental and Nonprofit Accounting, 5, $165-185$.

Aksakal, E., \& Dağdeviren, M. (2010). ANP ve Dematel Yöntemleri ile Personel Seçimi Problemine Bütünleşik Bir Yaklaşım. Gazi Üniversitesi Mühendislik-Mimarlık Fakültesi Dergisi, 25(4), 905913.

Altuntas, S., Selim, H., \& Dereli, T. (2014). A fuzzy DEMATEL-based solution approach for facility layout problem: a case study. The International Journal of Advanced Manufacturing Technology, 73(5-8), 749-771.

Arcelus, F. J., \& Coleman, D. F. (1997). An efficiency review of university departments. International Journal of Systems Science, 28(7), 721-729. reviewed journal, proceedings) were found to be noncritical in efficiency measurement. Analysis of the results shows that number of academic publications varies according to the values of other output factors. Therefore this factor is considered as unnecessary output in efficiency measurement of university departments.

\section{Conclusions}

Successful efficiency measurement of university departments is very important issue in today's globalized world and depends on paying high attention on critical input and output factors affecting efficiency measurement. In our study, we analyzed 15 critical input and 8 critical output factors by using fuzzy DEMATEL methodology which serves a highly effective structural decision making system for modeling cause and effect relationships. Among 15 critical input factors, Number of Academic Staff, Number of Undergraduate Students, Number of MSc. Students, Number of PhD. Students, Total Department Expenditures, Research Budget, Department Budget and Number of Laboratories and among 8 critical output factors Number of Papers Published in Academic Journals (SCI, SSCI), Number of Undergraduate Awards, Number of Postgraduate Awards and Number of Doctorates Awards are found to be the most important factors that influenced other factors.

This study is the first reference in the literature which uses a fuzzy DEMATEL technique in determination of effective critical input and output factors in successful efficiency measurement of university departments. As an extension of our work, the usage of critical inputs and outputs (determined as cause groups in this study) in the university departments' efficiency measurements via DEA gives researchers more reliable efficiency scores comparing to selection of inputs and outputs conceptually or intuitively.

Athanassopoulos, A. D., \& Shale, E. (1997). Assessing the comparative efficiency of higher education institutions in the UK by means of data envelopment analysis. Education Economics, 5(2), 117-134.

Avkiran, N. K. (2001). Investigating technical and scale efficiencies of Australian universities through data envelopment analysis. SocioEconomic Planning Sciences, 35(1), 57-80.

Baykasoglu, A., \& Durmusoglu, Z. D. U. (2014). A Hybrid MCDM for Private Primary School Assessment Using DEMATEL Based on ANP and Fuzzy Cognitive Map. International Journal of Computational Intelligence Systems, 7(4), 615-635.

Beasley, J. E. (1990). Comparing university departments. Omega International Journal of Management Science, 18(2), 171-183.

Beasley, J. E. (1995). Determining teaching and research efficiencies. Journal of the Operational Research Society, 46(4), 441-452.

Bellman, R.E., \& Zadeh, L.A. (1970). Decision-making in a fuzzy environment, Management Science, 17, 141-164.

Bessent, A. M., Bessent, E. W., Charnes, A., Cooper, W. W., \& Thorogood, N. C. (1983). Evaluation of educational program proposals by means of DEA. Educational Administration Quarterly, 19(2), 82-107. 
Breu, T. M., \& Raab, R. L. (1994). Efficiency and perceived quality of the nation's "Top 25" national universities and national liberal arts colleges: An application of data envelopment analysis to higher education. Socio-Economic Planning Sciences, 28(1), 33-45.

Büyüközkan, G., \& Çifçi, G. (2012). A novel hybrid MCDM approach based on fuzzy DEMATEL, fuzzy ANP and fuzzy TOPSIS to evaluate green suppliers. Expert Systems with Applications, 39(3), 3000-3011.

Casu, B., \& Thanassoulis, E. (2006). Evaluating cost efficiency in central administrative services in UK universities. Omega, 34, 417-426.

Cave, M., Hanney, S., \& Kogan, M. (1991). The Use of performance indicators in higher education: A critical analysis of developing practice. London: Jessica Kingsley Publishers.

Chalmers, D. (2008). Teaching and Learning Quality Indicators in Australian Universities. IMHE/OECD conference. The quality, relevance and impact of higher education. Paris.

Chang, B., Chang, C., \& Wu, C. (2011). Fuzzy DEMATEL method for developing supplier selection criteria, Expert Systems with Applications, 38, 1850-1858.

Chou, Y.-C., Sun, C.-C., \& Yen, H.-Y. (2012). Evaluating the criteria for human resource for science and technology (HRST) based on an integrated fuzzy AHP and fuzzy DEMATEL approach. Applied Soft Computing, 12(1), 64-71.

Coelli, T. (1996). Assessing the Performance of Australian Universities Using Data Envelopment Analysis. Mimeo. Center for Efficiency and Productivity Analysis. NSW: University of New England.

Coelli, T., Rao, D. S. P., \& Battese, G. E. (1998). An Introduction to Efficiency and Productivity Analysis. Kluwer Academic Publishers, Boston, $271 \mathrm{pp}$.

El Mahgary, S., \& Lahdelma, R. (1995). Data envelopment analysis: Visualizing the results. European Journal of Operational Research, $85,700-710$.

Erüz E. (2005). Yeni Mali Yönetim Yapısında Performans Esaslı Bütçeleme, 20. Türkiye Maliye Sempozyumu, 23-27 Mayıs, Denizli, s.61

Flegg, A. T., \& Allen, D. O. (2007). Does expansion cause congestion? The case of the older British universities, 1994-2004. Education Economics, 15(1), 75-102.

Flegg, A. T., Allen, D. O., Field, K., \& Thurlow, T. W. (2004). Measuring the efficiency and productivity of British universities: An application of DEA and the Malmquist approach. Education Economics, 12(3), 231-249.

Fox, K. J., \& Milbourne, R. (1999). What determines research output of academic economists? Economic Record, 75, 256-267.

Friedman, L., \& Sinuany-Stern, Z. (1997). Scaling units via the canonical correlation analysis in the data envelopment analysis context. European Journal of Operational Research, 100, 629-637.

Gabus, A., \& Fontela, E. (1972). World problems an invitation to further thought within the framework of DEMATEL, Battelle Geneva Research Centre, Switzerland, Geneva.

Gabus, A., \& Fontela, E. (1973). Perceptions of the world problematique: Communication procedure, communicating with those bearing collective responsibility (DEMATEL report no. 1). Battelle Geneva Research Centre, Switzerland, Geneva.

Glass, J. C, McKillop, D. G., \& Hyndman, N. (1995). Efficiency in the provision of university teaching and research: An empirical analysis of UK universities. Journal of Applied Econometrics, 10(1), 61-72.

Haksever, C., \& Muragishi, Y. (1998). Measuring value in MBA programs. Education Economics, 6(1), 11-25.

Hsieh, T. Y., Lu, S. T., \& Tzeng, G. H. (2004). Fuzzy MCDM approach for planning and design tenders selection in public office buildings. International Journal of Project Management, 22(7), $573-584$.
Johnes J., \& Yu L., (2008). Measuring the Research Performance of Chinese Higher Education İnstitutions Using Data Envelopment Analysis. China Economic Review, 19, 679-696

Johnes, J. (1996). Performance assessment in higher education in Britain. European Journal of Operational Research, 89(1), 18-33.

Johnes, J. (2006). DEA and its application to the measurement of efficiency in higher education. Economics of Education Review, 25(3), 273-288.

Johnes, J. (2006). Measuring teaching efficiency in higher education: An application of data envelopment analysis to Economics graduates from UK universities. European Journal of Operational Research, 174, 443-456

Katharaki M., \& Katharakis G. (2010). A Comparative Assessment of Greek Universities' Efficiency Using Quantitative Analysis. International Journal of Educational Research, 49(4-5), 115-128

Koksal G., \& Nalcaci B. (2006). The Relative Efficiency of Departments at a Turkish Engineering College: A Data Envelopment Analysis. Higher Education, 51, 173-189.

Mavi, R. K., \& Shahabi, H. (2015). Using fuzzy DEMATEL for evaluating supplier selection criteria in manufacturing industries. International Journal of Logistics Systems and Management, 22(1), $15-42$.

McMillan, M. L., \& Datta, D. (1998). The relative efficiency of Canadian universities. Canadian Public Policy, 24(4), 485-511.

Mokhtarian, M. N. (2007). Developing global manager's competencies using the fuzzy DEMATEL method. Expert Systems with Applications, 32(7), 9050-9051

OECD. (2007). Education at a Glance. Retrieved December 12, 2015 from: https://www.oecd.org/education/skills-beyondschool/40701218.pdf.

Organ, A. (2013). Bulanık Dematel Yöntemiyle Makine Seçimini Etkileyen Kriterlerin Değerlendirilmesi. Çukurova Üniversitesi Sosyal Bilimler Enstitüsü Dergisi, 22(1), 157-172.

Ortíz, M. A., Felizzola, H. A., \& Isaza, S. (2015). A contrast between DEMATEL-ANP and ANP methods for six sigma project selection: a case study in healthcare industry. BMC Medical Informatics and Decision Making, 15(Suppl 3), S3.

Oruc K.O. (2008). Efficiency Measurements in Fuzzy Environment by Using Data Envelopment Analysis and an Application at Universities, Süleyman Demirel University, Department of Business Administration, Ph.D.

Pereira, A. P., \& Tavares, A. F. (2002). O Uso de Indicadores de Performance na Avaliac,a a de Ensino Superior. Revista de Administrac a o e Polı'ticas Pu'blicas, 3(1-2), 82-94.

Preeti T., Shiv P.Y., \& Singh S.P. (2009).Relative Performance of Academic Departments Using DEA With Sensitivity Analysis, Evaluation and Program Planning, 32(2), 168-177

Salerno, C. (2006). Using data envelopment analysis to improve estimates of higher education institution's per student education costs. Education Economics, 14(3), 281-295.

Sener, Z. (2016). Evaluating Ship Selection Criteria for Maritime Transportation. Journal of Advanced Management Science, 4(4), 325-328.

Stevens, P. A. (2001). The Determinants of economic efficiency in English and Welsh universities. London: National Institute of Economic and Social Research. Discussion Paper no. 185.

Tsai, S.-B., Chien, M.-F., Xue, Y., Li, L., Jiang, X., Chen, Q., Zhou, J., \& Wang, L. (2015). Using the Fuzzy DEMATEL to Determine Environmental Performance: A Case of Printed Circuit Board Industry in Taiwan. PLOS ONE, 10(6), e0129153.

Tseng, M.-L. (2009). A causal and effect decision making model of service quality expectation using grey-fuzzy DEMATEL approach Expert Systems with Applications, 36(4), 7738-7748.

Vinodh, S., \& Swarnakar, V. (2015). Lean Six Sigma project selection using hybrid approach based on fuzzy DEMATEL-ANP-TOPSIS International Journal of Lean Six Sigma, 6(4), 313-338. 
Ward, D. (2007). Academic values, institutional management, and public policies. Higher Education Management and Policy, 19(2), $1-12$.

Worthington, A. (2001). An Empirical survey of frontier efficiency measurement techniques in education. Education Economics, 9(3), 245-268.

Worthington, A. C., \& Lee, B. L. (2008). Efficiency, technology and productivity change in Australian universities 1998-2003. Economics of Education Review, 27(3), 285-298.

Wu, W.-W., \& Lee, Y.-T. (2007). Developing global managers' competencies using the fuzzy DEMATEL method. Expert Systems with Applications, 32, 499-507.

YÖK (Yüksek Öğretim Kurumu). (2007). Türkiyenin Yüksek Öğrenim Stratejisi. (Yayın No: 2007-1), Ankara, YÖK.

Zadeh, L.A. (1965). Fuzzy sets, Information and Control, 8, 338-353.

Zhou, Q., Huang, W., \& Zhang, Y. (2011). Identifying critical success factors in emergency management using a fuzzy DEMATEL method, Safety Science, 49, 243-252. 
Appendix.

Table 1. Assessment Data of an Expert for Input Factors in Triangular Fuzzy Numbers

\begin{tabular}{|c|c|c|c|c|c|c|c|c|c|c|c|c|c|c|c|c|c|c|c|c|c|c|c|c|c|c|c|c|c|c|c|c|c|c|c|c|c|c|c|c|c|}
\hline \multicolumn{3}{|c|}{$\mathrm{C}_{\mathrm{in}} 1$} & \multicolumn{3}{|c|}{$\mathrm{C}_{\text {in }} 2$} & \multicolumn{3}{|c|}{$\mathrm{C}_{\text {in }} 3$} & \multicolumn{3}{|c|}{$\mathrm{C}_{\text {in }} 4$} & \multicolumn{3}{|c|}{$\mathrm{C}_{\mathrm{in}} 5$} & \multicolumn{3}{|c|}{$\mathrm{C}_{\text {in }} 6$} & \multicolumn{3}{|c|}{$\mathrm{C}_{\text {in }} 7$} & \multicolumn{3}{|c|}{$\mathrm{C}_{\text {in }} 8$} & \multicolumn{3}{|c|}{$\mathrm{C}_{\text {in }} 9$} & \multicolumn{2}{|c|}{$\mathrm{C}_{\mathrm{in}} 10$} & \multicolumn{3}{|c|}{$\mathrm{C}_{\mathrm{in}} 11$} & \multicolumn{3}{|c|}{$\mathrm{C}_{\text {in }} 12$} & \multicolumn{2}{|c|}{$\mathrm{C}_{\mathrm{in}} 13$} & \multicolumn{3}{|c|}{$\mathrm{C}_{\text {in }} 14$} & \multicolumn{2}{|c|}{$\mathrm{C}_{\text {in }} 15$} \\
\hline$l$ & $m$ & $u$ & $l$ & $m$ & $u$ & $l$ & $m$ & $u$ & $l$ & $n$ & & $l$ & $m$ & $u$ & $l$ & $m$ & & $l$ & & $u$ & $l$ & $m$ & $u$ & $l$ & $m u$ & $\iota$ & $l$ & $u$ & $l$ & $m$ & $u$ & $l$ & $m \mid l$ & $u$ & $l$ & $m u$ & $l$ & $m$ & $u$ & $l \quad r$ & $n u$ \\
\hline & & & & $\stackrel{n}{0}$ & & ? & ?: & $\stackrel{n}{0}$ & ?. & & & ב̂. & & & s. & $?$ & & 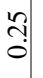 & $?$ & $\stackrel{n}{?}$ & 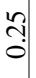 & 0 & & 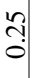 & $\because$ & $\frac{f}{b}$ & & $b \begin{array}{l}n \\
0 \\
0\end{array}$ & 0 & ֻุ & $\because$ & 0 & 0 & $\stackrel{0}{0}$ & & & $\stackrel{n}{o}$ & & & & ?. \\
\hline
\end{tabular}

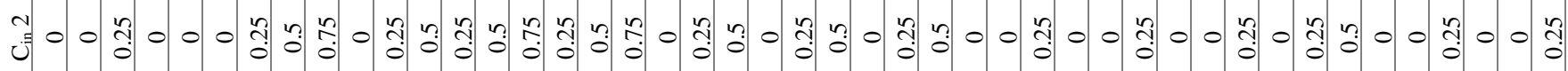
m.

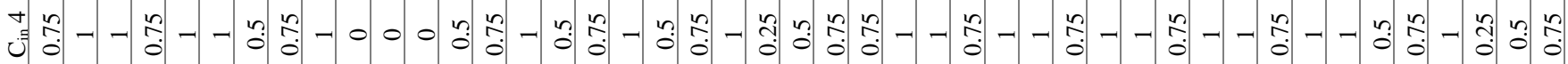

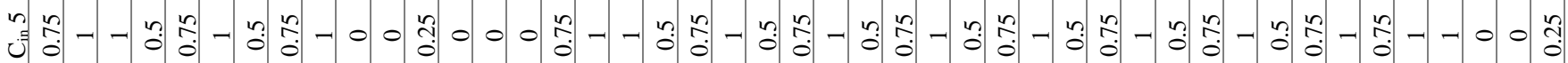
نำ Jै ن Jீ

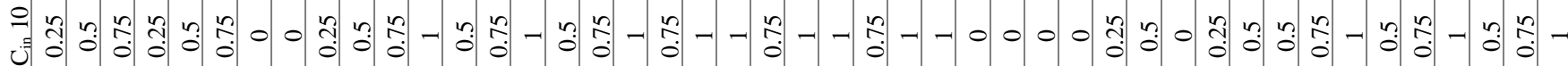

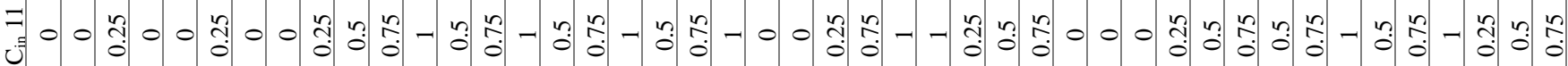
บี v J

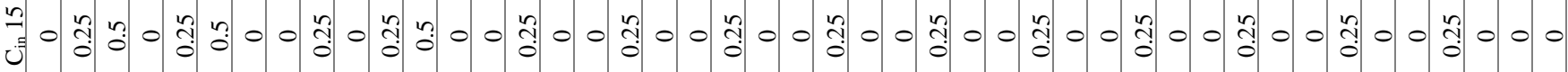


Table 2. Assessment Data of an Expert for Output Factors in Triangular Fuzzy Numbers

\begin{tabular}{|c|c|c|c|c|c|c|c|c|c|c|c|c|c|c|c|c|c|c|c|c|c|c|c|c|}
\hline & \multicolumn{3}{|c|}{$\mathrm{C}_{\text {out }} 1$} & \multicolumn{3}{|c|}{$\mathrm{C}_{\text {out }} 2$} & \multicolumn{3}{|c|}{$\mathrm{C}_{\text {out }} 3$} & \multicolumn{3}{|c|}{$\mathrm{C}_{\text {out }} 4$} & \multicolumn{3}{|c|}{$\mathrm{C}_{\text {out }} 5$} & \multicolumn{3}{|c|}{$\mathrm{C}_{\text {out }} 6$} & \multicolumn{3}{|c|}{$\mathrm{C}_{\text {out }} 7$} & \multicolumn{3}{|c|}{$\mathrm{C}_{\text {out }} 8$} \\
\hline & $l$ & $m$ & $u$ & $l$ & $m$ & $u$ & $l$ & $m$ & $u$ & $l$ & $m$ & $u$ & $l$ & $m$ & $u$ & $l$ & $m$ & $u$ & $l$ & $m$ & $u$ & $l$ & $m$ & $u$ \\
\hline$\overline{\overline{0}}$ & 0 & 0 & 0 & $\stackrel{n}{\stackrel{n}{0}}$ & - & - & $\tilde{n}$ & $\stackrel{n}{\stackrel{n}{0}}$ & - & ָั & $\because$ & $\frac{n}{2}$ & 0 & 0 & $\stackrel{n}{n}$ & 0 & 0 & 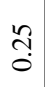 & 0 & 0 & ก̊ & 0 & ก̊ & $\tilde{c}$ \\
\hline$\overbrace{\overline{0}}^{\mathcal{O}}$ & $\dddot{n}$ & $\stackrel{n}{\stackrel{0}{o}}$ & - & 0 & 0 & 0 & $\stackrel{\text { Î }}{0}$ & $\because$ & $\stackrel{n}{\stackrel{n}{0}}$ & 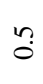 & $\stackrel{n}{\mathfrak{o}}$ & - & 0 & 0 & 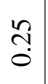 & 0 & $\stackrel{\sim}{\tilde{c}}$ & $\because$ & 0 & 0 & $\stackrel{\text { ñ }}{3}$ & 0 & 0 & ๙ุ \\
\hline ن) & ֶ̃ & $\tilde{n}$ & $\stackrel{n}{\stackrel{2}{o}}$ & 0 & ָึ & $\because$ & 0 & 0 & 0 & 0 & 0 & $\stackrel{\text { ât }}{3}$ & 0 & 0 & 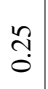 & 0 & 0 & $\stackrel{\text { ra }}{o}$ & 0 & 0 & ֶ̊ & 0 & 0 & ָุ \\
\hline$\underbrace{+\overline{0}}$ & $\tilde{n}$ & $\stackrel{n}{\stackrel{n}{0}}$ & - & $\tilde{0}$ & $\stackrel{n}{\stackrel{n}{o}}$ & - & $\stackrel{n}{\stackrel{0}{0}}$ & - & - & 0 & 0 & 0 & 0 & ֶֻ. & 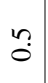 & $n$ & $\stackrel{n}{\mathfrak{o}}$ & - & $\ddot{0}$ & $\frac{n}{o}$ & - & $\stackrel{n}{\mathfrak{0}}$ & - & - \\
\hline نn & 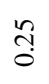 & $\dddot{n}$ & $\stackrel{n}{\stackrel{2}{0}}$ & 0 & ָ̃ & $\tilde{0}$ & $\stackrel{\sim}{\tilde{c}}$ & ?n? & $\stackrel{n}{\stackrel{n}{0}}$ & ָิ & 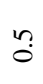 & $\stackrel{n}{\stackrel{n}{0}}$ & 0 & 0 & 0 & $\stackrel{n}{\tilde{o}}$ & - & - & 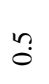 & $\frac{n}{o}$ & - & 0 & ֶ̊ & $\tilde{c}$ \\
\hline $\begin{array}{l}0 \\
\overline{\bar{z}} \\
0\end{array}$ & $\tilde{n}$ & $\stackrel{n}{\tilde{o}}$ & - & $\tilde{n}$ & $\stackrel{n}{\stackrel{2}{0}}$ & - & $\stackrel{n}{\stackrel{n}{0}}$ & - & - & $\tilde{n}$ & $\stackrel{n}{o}$ & - & 0 & 0 & 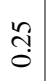 & 0 & 0 & 0 & $\stackrel{n}{\tilde{0}}$ & - & - & $\tilde{0}$ & $\stackrel{n}{\stackrel{2}{o}}$ & - \\
\hline 言 & $\tilde{n}$ & $\stackrel{n}{\stackrel{n}{0}}$ & - & $\stackrel{n}{0}$ & - & - & $n$ & $\frac{n}{o}$ & - & ֶ̃ & $\tilde{n}$ & $\stackrel{n}{\stackrel{n}{o}}$ & 0 & 0 & 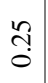 & 0 & 0 & ֶָ. & 0 & 0 & 0 & 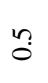 & $\stackrel{n}{\stackrel{0}{o}}$ & - \\
\hline 訔 & 0 & ֶָ. & ? & $\stackrel{\text { an }}{0}$ & $\because$ & $\stackrel{n}{\stackrel{n}{o}}$ & 0 & ֻึ & $\tilde{n}$ & ? & $\stackrel{n}{a}$ & - & ֶ̃ & 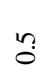 & $\stackrel{n}{\stackrel{n}{0}}$ & 0 & ปิ & $\because$ & 0 & ปึ. & $\because$ & 0 & 0 & 0 \\
\hline
\end{tabular}

Table 3. The Normalized Direct-Relation Matrix for Output Factors

\begin{tabular}{|c|c|c|c|c|c|c|c|c|c|c|c|c|c|c|c|c|c|c|c|c|c|c|c|c|}
\hline & \multicolumn{3}{|c|}{$\mathrm{C}_{\text {out }} 1$} & \multicolumn{3}{|c|}{$\mathrm{C}_{\text {out }} 2$} & \multicolumn{3}{|c|}{$\mathrm{C}_{\text {out }} 3$} & \multicolumn{3}{|c|}{$\mathrm{C}_{\text {out }} 4$} & \multicolumn{3}{|c|}{$\mathrm{C}_{\text {out }} 5$} & \multicolumn{3}{|c|}{$\mathrm{C}_{\text {out }} 6$} & \multicolumn{3}{|c|}{$\mathrm{C}_{\text {out }} 7$} & \multicolumn{3}{|c|}{$\mathrm{C}_{\text {out }} 8$} \\
\hline & $l$ & $m$ & $u$ & $l$ & $m$ & $u$ & $l$ & $m$ & $u$ & $l$ & $m$ & $u$ & $l$ & $m$ & $u$ & $l$ & $m$ & $u$ & $l$ & $m$ & $u$ & $l$ & $m$ & $u$ \\
\hline 豙 & $\begin{array}{l}8 \\
8 \\
8 \\
0\end{array}$ & $\begin{array}{l}8 \\
8 \\
0 \\
0\end{array}$ & \begin{tabular}{l}
$\stackrel{8}{0}$ \\
\hdashline \\
\end{tabular} & $\begin{array}{l}\stackrel{a}{0} \\
\text { : } \\
0\end{array}$ & 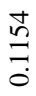 & 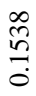 & $\begin{array}{l}\hat{D} \\
\stackrel{0}{0} \\
\stackrel{0}{0}\end{array}$ & $\begin{array}{l}\stackrel{ \pm}{\leftrightarrows} \\
\stackrel{0}{0}\end{array}$ & $\frac{\infty}{n} \underset{n}{n}$ & 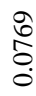 & $\begin{array}{l}\stackrel{+}{n} \\
\Xi \\
\end{array}$ & 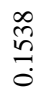 & $\begin{array}{l}8 \\
8 \\
8 \\
0\end{array}$ & $\begin{array}{l}8 \\
8 \\
8 \\
0 \\
0\end{array}$ & $\begin{array}{l}n \\
\infty \\
\\
\stackrel{0}{0} \\
0\end{array}$ & $\begin{array}{l}8 \\
8 \\
8 \\
\circ\end{array}$ & \begin{tabular}{l}
8 \\
8 \\
8 \\
\hdashline
\end{tabular} & 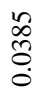 & \begin{tabular}{l}
8 \\
8 \\
8 \\
\hdashline
\end{tabular} & $\begin{array}{l}8 \\
8 \\
8 \\
0\end{array}$ & 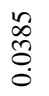 & 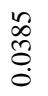 & $\begin{array}{l}\hat{0} \\
\stackrel{0}{0} \\
0\end{array}$ & $\begin{array}{l}\stackrel{+}{n} \\
\exists \\
\end{array}$ \\
\hline$\overbrace{}^{\mathcal{O}}$ & 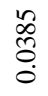 & $\begin{array}{l}8 \\
\text { Lे } \\
0 \\
0\end{array}$ & $\begin{array}{l}\text { 总 } \\
= \\
\end{array}$ & $\begin{array}{l}8 \\
8 \\
0 \\
0\end{array}$ & \begin{tabular}{l}
8 \\
8 \\
\hdashline \\
\hdashline
\end{tabular} & $\begin{array}{l}8 \\
8 \\
0 \\
0\end{array}$ & $\begin{array}{l}\stackrel{0}{0} \\
\stackrel{0}{0} \\
\stackrel{0}{0}\end{array}$ & $\begin{array}{l}\stackrel{t}{n} \\
= \\
\end{array}$ & $\frac{\infty}{n} \underset{n}{n}$ & $\begin{array}{l}\text { ò } \\
\text { ㅇ. }\end{array}$ & $\begin{array}{l}\stackrel{+}{2} \\
= \\
\end{array}$ & $\frac{\infty}{\stackrel{\infty}{n}}$ & $\begin{array}{l}\text { \&ి } \\
: \\
0\end{array}$ & \begin{tabular}{l}
8 \\
8 \\
\hdashline \\
\hdashline
\end{tabular} & 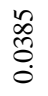 & $\begin{array}{l}\text { \&̊ } \\
: \\
0\end{array}$ & \begin{tabular}{l}
8 \\
8 \\
\hdashline \\
\hdashline
\end{tabular} & 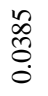 & \begin{tabular}{l}
8 \\
8 \\
8 \\
\hdashline
\end{tabular} & \begin{tabular}{l}
8 \\
8 \\
8 \\
\hdashline
\end{tabular} & 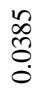 & \begin{tabular}{l}
8 \\
8 \\
8 \\
\hdashline
\end{tabular} & $\begin{array}{l}8 \\
8 \\
8 \\
0\end{array}$ & 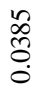 \\
\hline نे & $\begin{array}{l}0 \\
\infty \\
\tilde{O} \\
\stackrel{0}{0}\end{array}$ & $\begin{array}{l}8 \\
\text { oे } \\
0 \\
0\end{array}$ & $\begin{array}{l}\stackrel{+}{0} \\
= \\
\end{array}$ & $\begin{array}{l}\mathscr{\infty} \\
\tilde{O} \\
\ddot{0}\end{array}$ & $\begin{array}{l}\text { aे } \\
\text { o. } \\
\stackrel{0}{0}\end{array}$ & 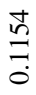 & \begin{tabular}{l}
8 \\
8 \\
8 \\
\hdashline \\
0
\end{tabular} & $\begin{array}{l}8 \\
8 \\
8 \\
0\end{array}$ & \begin{tabular}{l}
8 \\
\hdashline \\
\hdashline
\end{tabular} & $\begin{array}{l}8 \\
8 \\
8 \\
0\end{array}$ & $\begin{array}{l}8 \\
8 \\
8 \\
0\end{array}$ & $\begin{array}{l}\mathscr{0} \\
\text { లె } \\
\stackrel{0}{0}\end{array}$ & $\begin{array}{l}8 \\
8 \\
8 \\
0\end{array}$ & $\begin{array}{l}8 \\
8 \\
8 \\
0\end{array}$ & $\begin{array}{l}\mathscr{1} \\
\text { లె } \\
\stackrel{0}{0}\end{array}$ & $\begin{array}{l}8 \\
8 \\
8 \\
0\end{array}$ & \begin{tabular}{l}
8 \\
8 \\
8 \\
\hdashline
\end{tabular} & 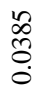 & $\begin{array}{l}8 \\
8 \\
8 \\
0\end{array}$ & $\begin{array}{l}8 \\
8 \\
8 \\
0\end{array}$ & 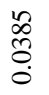 & \begin{tabular}{l}
8 \\
8 \\
8 \\
\hdashline
\end{tabular} & $\begin{array}{l}8 \\
8 \\
8 \\
0\end{array}$ & $\begin{array}{l}\mathscr{\infty} \\
\tilde{O} \\
\stackrel{0}{0}\end{array}$ \\
\hline$\overbrace{}^{+\overline{0}}$ & $\begin{array}{l}\stackrel{+}{n} \\
\stackrel{0}{0}\end{array}$ & $\begin{array}{l}\infty \\
\stackrel{\sim}{n} \\
\stackrel{0}{0}\end{array}$ & $\begin{array}{l}\stackrel{\infty}{\approx} \\
\stackrel{2}{0} \\
0\end{array}$ & $\begin{array}{l}\stackrel{+}{O} \\
=\end{array}$ & $\begin{array}{l}\stackrel{\infty}{n} \\
\stackrel{n}{\circ} \\
\stackrel{0}{0}\end{array}$ & $\begin{array}{l}\stackrel{\infty}{n} \\
\stackrel{n}{2} \\
0\end{array}$ & $\begin{array}{l}\stackrel{+}{\leftrightarrows} \\
\stackrel{0}{0}\end{array}$ & $\frac{\infty}{n}$ & $\stackrel{\infty}{\substack{n \\
\stackrel{0}{0}}}$ & $\begin{array}{l}8 \\
8 \\
8 \\
0\end{array}$ & $\begin{array}{l}8 \\
8 \\
8 \\
0\end{array}$ & \begin{tabular}{l}
8 \\
8 \\
8 \\
\hdashline
\end{tabular} & $\begin{array}{l}8 \\
8 \\
8 \\
0\end{array}$ & 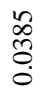 & $\begin{array}{l}\hat{0} \\
\text { 今̦ } \\
\stackrel{0}{0}\end{array}$ & $\begin{array}{l}\hat{D} \\
\text { 웅 }\end{array}$ & $\begin{array}{l}\stackrel{ \pm}{=} \\
\overrightarrow{0}\end{array}$ & $\frac{\infty}{\stackrel{\infty}{n}}$ & $\begin{array}{l}\hat{0} \\
\text { 今े } \\
\stackrel{0}{0}\end{array}$ & 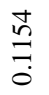 & 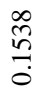 & $\begin{array}{l}\stackrel{+}{\leftrightarrows} \\
\Xi \\
\end{array}$ & $\frac{\infty}{\stackrel{\infty}{n}}$ & 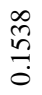 \\
\hline ن & $\begin{array}{l}n \\
\infty \\
\tilde{c} \\
\stackrel{0}{0}\end{array}$ & $\begin{array}{l}8 \\
\text { Lे } \\
0 \\
0\end{array}$ & $\begin{array}{l}\text { 总 } \\
=\end{array}$ & \begin{tabular}{l}
$\mathscr{2}$ \\
$\infty$ \\
\hdashline \\
0 \\
0
\end{tabular} & $\begin{array}{l}\text { aे } \\
\text { : } \\
0\end{array}$ & $\begin{array}{l}\stackrel{\text { In }}{=} \\
0\end{array}$ & 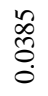 & $\begin{array}{l}\stackrel{0}{0} \\
\stackrel{0}{0} \\
\stackrel{0}{0}\end{array}$ & $\begin{array}{l}\text { in } \\
= \\
0\end{array}$ & 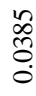 & $\begin{array}{l}\text { Oे } \\
\text { ํ. } \\
\text {. }\end{array}$ & 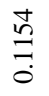 & $\begin{array}{l}8 \\
8 \\
8 \\
0\end{array}$ & 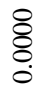 & 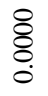 & $\begin{array}{l}\stackrel{+}{2} \\
=\end{array}$ & $\frac{\infty}{\stackrel{\infty}{n}}$ & $\frac{\infty}{\stackrel{\infty}{n}}$ & 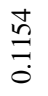 & $\frac{\infty}{\stackrel{n}{n}}$ & $\frac{\infty}{n}$ & 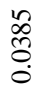 & $\begin{array}{l}\hat{0} \\
\stackrel{0}{0} \\
0\end{array}$ & $\begin{array}{l}\stackrel{+}{6} \\
\stackrel{5}{0}\end{array}$ \\
\hline $\begin{array}{l}0 \\
\text { 言 }\end{array}$ & $\begin{array}{l}\hat{0} \\
\text { ㅇ. } \\
\stackrel{0}{0}\end{array}$ & $\begin{array}{l}\stackrel{+}{=} \\
\stackrel{0}{0}\end{array}$ & $\begin{array}{l}\stackrel{\infty}{n} \\
\stackrel{n}{0} \\
0\end{array}$ & $\begin{array}{l}\stackrel{8}{0} \\
\text { o. } \\
\stackrel{0}{0}\end{array}$ & $\begin{array}{l}\stackrel{\text { In }}{=} \\
0\end{array}$ & $\frac{\infty}{\stackrel{\infty}{n}} \stackrel{\text { on }}{\stackrel{0}{0}}$ & $\begin{array}{l}\text { ôे } \\
\stackrel{0}{0} \\
\stackrel{0}{0}\end{array}$ & $\begin{array}{l}\stackrel{ \pm}{\leftrightarrows} \\
\stackrel{0}{0}\end{array}$ & $\begin{array}{l}\infty \\
\stackrel{\infty}{n} \\
\stackrel{n}{0}\end{array}$ & $\begin{array}{l}\hat{0} \\
\text { S. } \\
\text {. }\end{array}$ & $\begin{array}{l}\stackrel{+}{n} \\
= \\
\end{array}$ & $\begin{array}{l}\infty \\
\stackrel{n}{n} \\
\stackrel{0}{0}\end{array}$ & $\begin{array}{l}8 \\
8 \\
8 \\
0\end{array}$ & $\begin{array}{l}8 \\
8 \\
8 \\
0\end{array}$ & $\begin{array}{l}n \\
\infty \\
\tilde{o}_{0} \\
\stackrel{0}{0}\end{array}$ & $\begin{array}{l}8 \\
8 \\
8 \\
\circ\end{array}$ & \begin{tabular}{l}
8 \\
8 \\
8 \\
\hdashline
\end{tabular} & $\begin{array}{l}8 \\
8 \\
8 \\
0 \\
0\end{array}$ & $\begin{array}{l}\stackrel{+}{\leftrightarrows} \\
\stackrel{0}{0}\end{array}$ & $\stackrel{\infty}{\stackrel{\infty}{n}}$ & $\begin{array}{l}\infty \\
\stackrel{n}{n} \\
\stackrel{0}{0}\end{array}$ & $\begin{array}{l}0 \\
\stackrel{0}{0} \\
\stackrel{0}{0}\end{array}$ & $\begin{array}{l}\stackrel{+}{\Xi} \\
\stackrel{0}{0}\end{array}$ & $\begin{array}{l}\stackrel{\infty}{\bumpeq} \\
\stackrel{2}{0} \\
0\end{array}$ \\
\hline$\overline{\bar{v}}$ & $\begin{array}{l}0 \\
0 \\
0 \\
0\end{array}$ & $\frac{\stackrel{+}{6}}{=}$ & 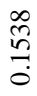 & $\begin{array}{l}\text { aे } \\
\text { : } \\
0\end{array}$ & $\frac{\stackrel{H}{n}}{=}$ & $\begin{array}{l}\stackrel{\infty}{n} \\
\stackrel{n}{\circ} \\
\stackrel{0}{0}\end{array}$ & $\begin{array}{l}\hat{0} \\
\text { 今़ } \\
\stackrel{0}{0}\end{array}$ & $\begin{array}{l}\stackrel{+}{=} \\
\stackrel{0}{0}\end{array}$ & $\begin{array}{l}\infty \\
\stackrel{\infty}{n} \\
\stackrel{n}{0}\end{array}$ & $\begin{array}{l}0 \\
\stackrel{0}{0} \\
\stackrel{0}{0}\end{array}$ & $\begin{array}{l}\stackrel{+}{n} \\
\Xi \\
0\end{array}$ & $\frac{\infty}{n}$ & $\begin{array}{l}8 \\
8 \\
8 \\
0\end{array}$ & $\begin{array}{l}8 \\
8 \\
8 \\
0\end{array}$ & 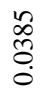 & $\begin{array}{l}8 \\
8 \\
8 \\
0\end{array}$ & $\begin{array}{l}8 \\
8 \\
8 \\
0\end{array}$ & $\begin{array}{l}n \\
\infty \\
\tilde{o}_{0} \\
\stackrel{0}{0}\end{array}$ & $\begin{array}{l}8 \\
8 \\
8 \\
0\end{array}$ & $\begin{array}{l}8 \\
8 \\
8 \\
0\end{array}$ & $\begin{array}{l}8 \\
8 \\
8 \\
0\end{array}$ & $\begin{array}{l}\hat{D} \\
\stackrel{0}{0} \\
\stackrel{0}{0}\end{array}$ & $\begin{array}{l}\stackrel{+}{=} \\
\stackrel{0}{0}\end{array}$ & 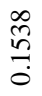 \\
\hline U $^{\infty}$ & $\begin{array}{l}8 \\
8 \\
8 \\
0\end{array}$ & 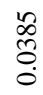 & $\begin{array}{l}\stackrel{8}{0} \\
\stackrel{0}{0} \\
\stackrel{0}{0}\end{array}$ & \begin{tabular}{l}
8 \\
8 \\
\hdashline \\
0
\end{tabular} & $\begin{array}{l}\mathscr{\infty} \\
\tilde{O} \\
\ddot{0}\end{array}$ & $\begin{array}{l}\text { iे } \\
\text { : } \\
0\end{array}$ & $\begin{array}{l}8 \\
8 \\
8 \\
0 \\
0\end{array}$ & 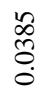 & $\begin{array}{l}\text { Oे } \\
\text { ¿े } \\
0\end{array}$ & $\stackrel{\stackrel{+}{2}}{=}$ & 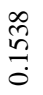 & $\frac{\infty}{\stackrel{\infty}{n}}$ & $\begin{array}{l}8 \\
8 \\
8 \\
0\end{array}$ & $\begin{array}{l}1 \\
\infty \\
\tilde{O}_{0} \\
\stackrel{0}{0}\end{array}$ & 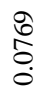 & $\begin{array}{l}8 \\
8 \\
8 \\
0\end{array}$ & 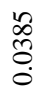 & $\begin{array}{l}\text { ôे } \\
\text { ọ. } \\
0\end{array}$ & $\begin{array}{l}8 \\
8 \\
8 \\
0 \\
0\end{array}$ & 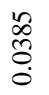 & $\begin{array}{l}\stackrel{0}{0} \\
\stackrel{0}{0} \\
\stackrel{0}{0}\end{array}$ & $\begin{array}{l}8 \\
8 \\
8 \\
0\end{array}$ & $\begin{array}{l}8 \\
8 \\
8 \\
0 \\
0\end{array}$ & \begin{tabular}{l}
8 \\
\hdashline \\
\hdashline
\end{tabular} \\
\hline
\end{tabular}


Table 4. The Normalized Direct-Relation Matrix for Input Factors

\begin{tabular}{|c|c|c|c|c|c|c|c|c|c|c|c|c|c|c|}
$\mathrm{C}_{\text {in }} 1$ & $\mathrm{C}_{\text {in }} 2$ & $\mathrm{C}_{\text {in }} 3$ & $\mathrm{C}_{\text {in }} 4$ & $\mathrm{C}_{\text {in }} 5$ & $\mathrm{C}_{\text {in }} 6$ & $\mathrm{C}_{\text {in }} 7$ & $\mathrm{C}_{\text {in }} 8$ & $\mathrm{C}_{\text {in }} 9$ & $\mathrm{C}_{\text {in }} 10$ & $\mathrm{C}_{\text {in }} 11$ & $\mathrm{C}_{\text {in }} 12$ & $\mathrm{C}_{\text {in }} 13$ & $\mathrm{C}_{\text {in }} 14$ & $\mathrm{C}_{\text {in }} 15$ \\
\hline
\end{tabular}

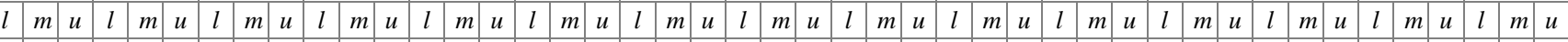

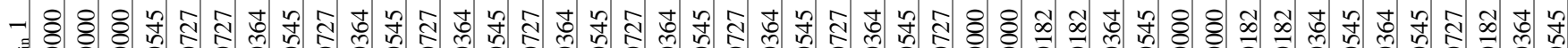
v

ง \& \& v : : :

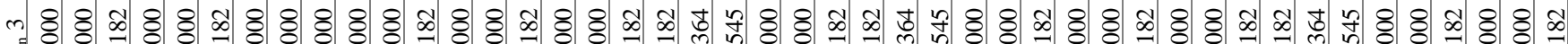

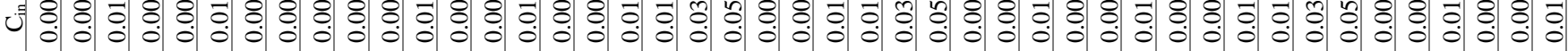

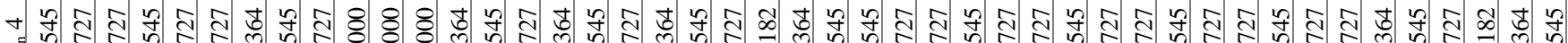

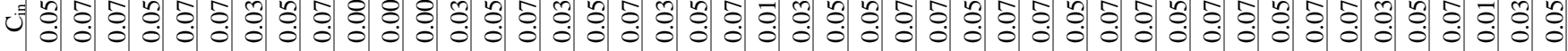

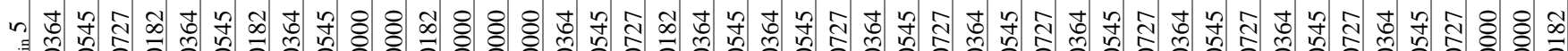
ن

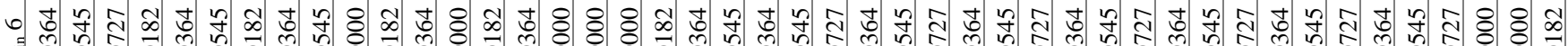
v

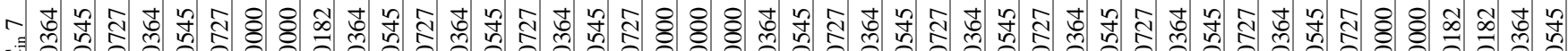
v 象

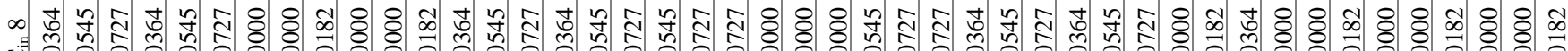

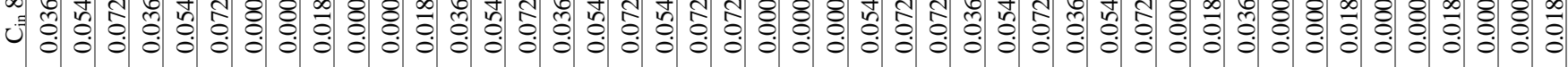

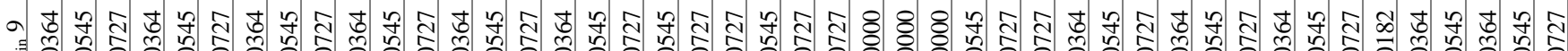

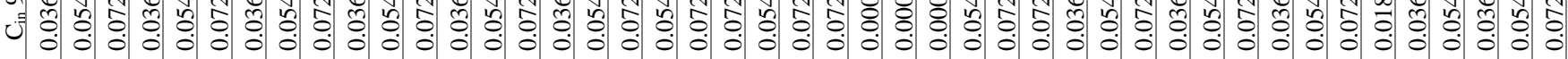

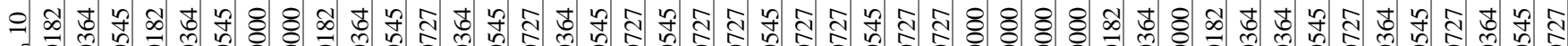
v

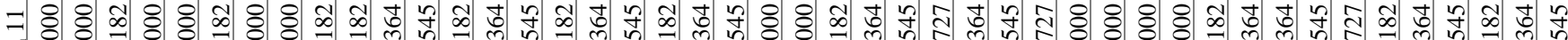
ن 告

궁ㅎㅇ \& ن :

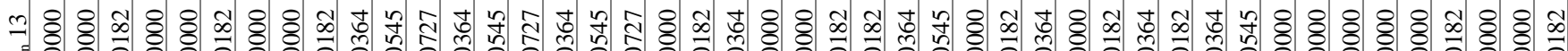
ن 告

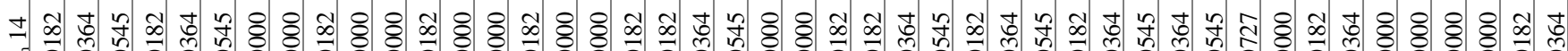
v

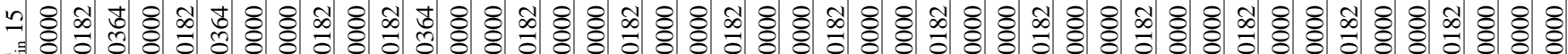
ن : 
Table 5. Total Relation Matrix for Input Factors

\begin{tabular}{|c|c|c|c|c|c|c|c|c|c|c|c|c|c|c|}
$\mathrm{C}_{\text {in }} 1$ & $\mathrm{C}_{\text {in }} 2$ & $\mathrm{C}_{\text {in }} 3$ & $\mathrm{C}_{\text {in }} 4$ & $\mathrm{C}_{\text {in }} 5$ & $\mathrm{C}_{\text {in }} 6$ & $\mathrm{C}_{\text {in }} 7$ & $\mathrm{C}_{\mathrm{in}} 8$ & $\mathrm{C}_{\text {in }} 9$ & $\mathrm{C}_{\text {in }} 10$ & $\mathrm{C}_{\text {in }} 11$ & $\mathrm{C}_{\text {in }} 12$ & $\mathrm{C}_{\text {in }} 13$ & $\mathrm{C}_{\text {in }} 14$ & $\mathrm{C}_{\text {in }} 15$ \\
\hline
\end{tabular} \begin{tabular}{l|l|l|l|l|l|l|l|l|l|l|l|l|l|l|l|l|l|l|l|l|l|l|l|l|l|l|l|l|l|l|l|l|l|l|l|l|l|l|l|l|l|l|l|l|}
\hline$l$ & $m$ & $u$ & $l$ & $m$ & $u$ & $l$ & $m$ & $u$ & $l$ & $m$ & $u$ & $l$ & $m$ & $u$ & $l$ & $m$ & $u$ & $l$ & $m$ & $u$ & $l$ & $m$ & $u$ & $l$ & $m$ & $u$ & $l$ & $m$ & $u$ & $l$ & $m$ & $u$ & $l$ & $m$ & $u$ & $l$ & $m$ & $u$ & $l$ & $m$ & $u$ & $l$ & $m$ & $u$ \\
\hline
\end{tabular}

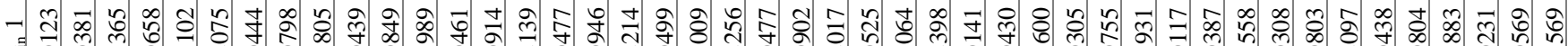
u

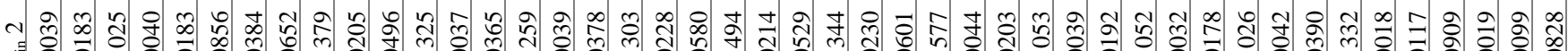
ن m v

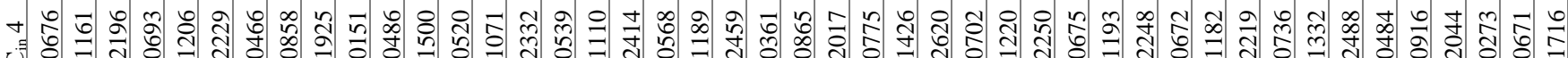

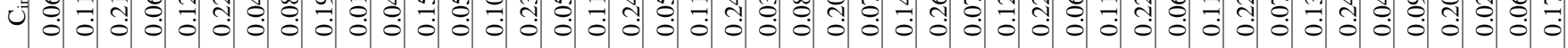

n v ○ 守苟

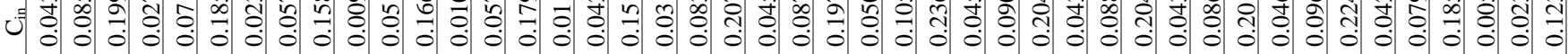

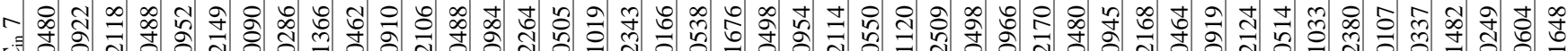
ن

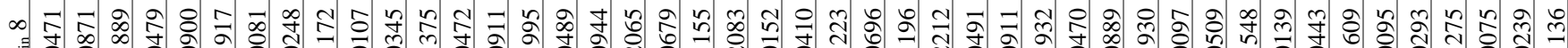

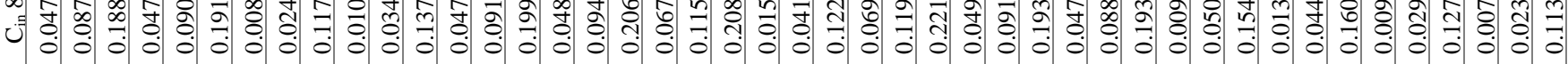

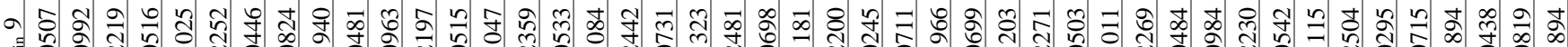
ن

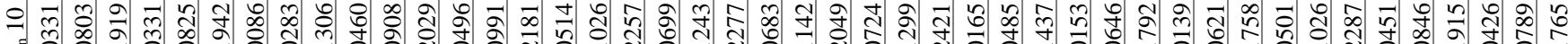

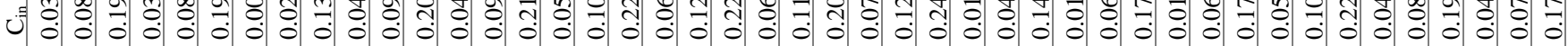

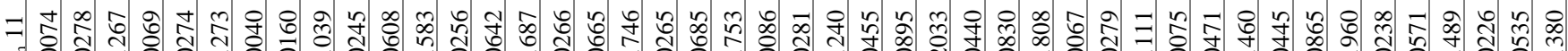

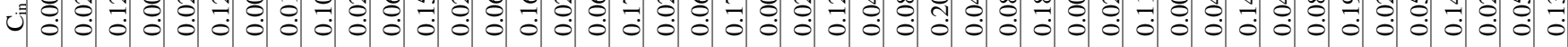

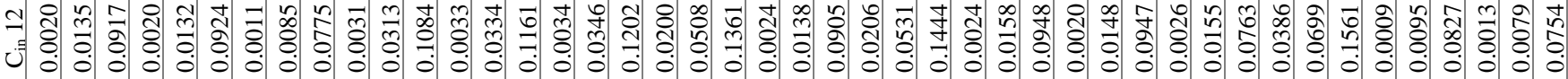

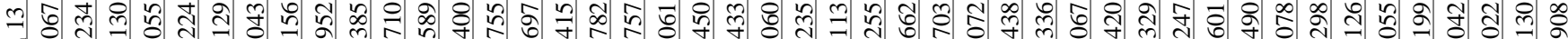
ن

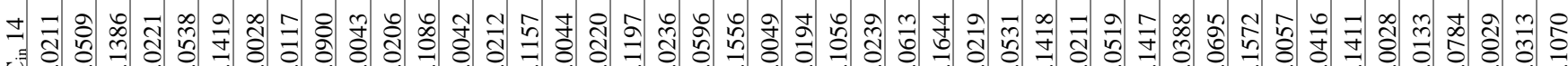
v

은 v 
Table 6. Total Relation Matrix for Output Factors

\begin{tabular}{|c|c|c|c|c|c|c|c|c|c|c|c|c|c|c|c|c|c|c|c|c|c|c|c|c|}
\hline & \multicolumn{3}{|c|}{$\mathrm{C}_{\text {out }} 1$} & \multicolumn{3}{|c|}{$\mathrm{C}_{\text {out }} 2$} & \multicolumn{3}{|c|}{$\mathrm{C}_{\text {out }} 3$} & \multicolumn{3}{|c|}{$\mathrm{C}_{\text {out }} 4$} & \multicolumn{3}{|c|}{$\mathrm{C}_{\text {out }} 5$} & \multicolumn{3}{|c|}{$\mathrm{C}_{\text {out }} 6$} & \multicolumn{3}{|c|}{$\mathrm{C}_{\text {out }} 7$} & \multicolumn{3}{|c|}{$\mathrm{C}_{\text {out }} 8$} \\
\hline & $l$ & $m$ & $u$ & $l$ & $m$ & $u$ & $l$ & $m$ & $u$ & $l$ & $m$ & $u$ & $l$ & $m$ & $u$ & $l$ & $m$ & $u$ & $l$ & $m$ & $u$ & $l$ & $m$ & $u$ \\
\hline$\overline{\overline{\bar{\theta}}}$ & $\frac{\sigma}{\partial}$ & 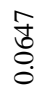 & $\begin{array}{l}\text { مి } \\
\text { ํ. } \\
\text {. }\end{array}$ & $\begin{array}{l}\text { + } \\
\text { Oे } \\
\stackrel{0}{0}\end{array}$ & $\frac{\vec{J}}{\stackrel{J}{0}}$ & $\begin{array}{l}\sqrt{0} \\
\stackrel{+}{0}\end{array}$ & 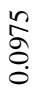 & $\frac{\hat{\sigma}}{\infty}$ & $\begin{array}{l}\stackrel{n}{0} \\
\stackrel{m}{+} \\
\stackrel{0}{0}\end{array}$ & $\begin{array}{l}\hat{\widehat{a}} \\
\stackrel{0}{0}\end{array}$ & $\frac{\infty}{\hat{0}}$ & $\begin{array}{l}\bar{a} \\
\text { +े } \\
\text { d. }\end{array}$ & $\begin{array}{l}8 \\
8 \\
8 \\
0\end{array}$ & $\begin{array}{l}\stackrel{8}{0} \\
0 \\
0\end{array}$ & $\frac{\text { I }}{\text { in }}$ & \begin{tabular}{l}
\multirow{5}{8}{} \\
0
\end{tabular} & $\begin{array}{l}\stackrel{+}{2} \\
\text { ơ } \\
0\end{array}$ & 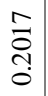 & $\begin{array}{l}8 \\
\stackrel{0}{8} \\
\stackrel{0}{0}\end{array}$ & $\begin{array}{l}\text { ¿े } \\
\text { ठ઼. } \\
\dot{0}\end{array}$ & $\begin{array}{l}\stackrel{+}{J} \\
\stackrel{\text { N }}{0}\end{array}$ & $\begin{array}{l}\bar{n} \\
\stackrel{n}{0} \\
0\end{array}$ & $\frac{g}{\stackrel{g}{+}}$ & 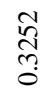 \\
\hline$\overbrace{}^{\stackrel{\bar{z}}{0}}$ & $\begin{array}{l}0 \\
\overparen{2} \\
\stackrel{0}{0}\end{array}$ & $\begin{array}{l}\underset{\approx}{\tilde{c}} \\
\stackrel{0}{0}\end{array}$ & $\begin{array}{l}\stackrel{0}{n} \\
\text { ?n } \\
0\end{array}$ & $\stackrel{\circ}{\stackrel{\infty}{\circ}} \stackrel{0}{\circ}$ & 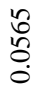 & 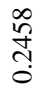 & 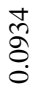 & $\frac{\sqrt{0}}{0}$ & $\begin{array}{l}\text { ลิ } \\
\text { กิ }\end{array}$ & $\begin{array}{l}0 \\
0 \\
0 \\
0 \\
0\end{array}$ & $\frac{\stackrel{?}{f}}{\stackrel{f}{0}}$ & $\begin{array}{l}n \\
2 \\
0 \\
0 \\
0\end{array}$ & \begin{tabular}{l}
8 \\
8 \\
\hdashline \\
0
\end{tabular} & 홍 & 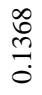 & $\begin{array}{l}\mathscr{8} \\
8 \\
0\end{array}$ & $\frac{n}{2}$ & $\frac{\substack{\hat{\sigma} \\
0}}{0}$ & $\begin{array}{l}\text { م્ } \\
\stackrel{8}{0} \\
\stackrel{0}{0}\end{array}$ & 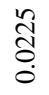 & $\frac{\widetilde{\sigma}}{\sigma}$ & $\begin{array}{l}\stackrel{1}{0} \\
0 \\
0\end{array}$ & 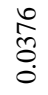 & 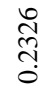 \\
\hline 党 & $\begin{array}{l}\stackrel{m}{g} \\
\stackrel{0}{0}\end{array}$ & $\begin{array}{l}\frac{J}{\sigma} \\
\stackrel{0}{0} \\
\stackrel{0}{0}\end{array}$ & 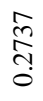 & 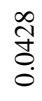 & $\begin{array}{l}\text { f } \\
\stackrel{8}{0} \\
\dot{0}\end{array}$ & 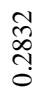 & $\begin{array}{l}\stackrel{0}{8} \\
\stackrel{8}{0}\end{array}$ & $\begin{array}{l}\stackrel{0}{\circ} \\
\text { ¿े } \\
\stackrel{0}{0}\end{array}$ & $\frac{\mathfrak{n}}{\stackrel{0}{0}}$ & $\begin{array}{l}\infty \\
\stackrel{0}{8} \\
\stackrel{0}{0} \\
\dot{0}\end{array}$ & 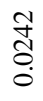 & $\frac{\infty}{n}$ & $\begin{array}{l}8 \\
8 \\
8 \\
0\end{array}$ & $\underset{0}{+}$ & $\begin{array}{l}0 \\
\infty \\
0 \\
0 \\
0\end{array}$ & $\begin{array}{l}\mathscr{8} \\
8 \\
8\end{array}$ & $\begin{array}{l}\tilde{n} \\
\stackrel{8}{8} \\
\dot{0}\end{array}$ & $\begin{array}{l}\text { D: } \\
\text { m. } \\
\stackrel{0}{0}\end{array}$ & $\begin{array}{l}0 \\
8 \\
8 \\
0\end{array}$ & $\begin{array}{l}\stackrel{+}{+} \\
8 \\
0\end{array}$ & $\frac{\infty}{\frac{\infty}{n}}$ & 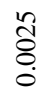 & 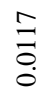 & $\begin{array}{l}\stackrel{\infty}{5} \\
\stackrel{5}{0}\end{array}$ \\
\hline نे & $\frac{n}{+}$ & $\begin{array}{l}\text { to } \\
\text { సै } \\
\text { o }\end{array}$ & $\begin{array}{l}8 \\
\text { N } \\
\text { ñ }\end{array}$ & $\frac{\stackrel{9}{n}}{0}$ & $\begin{array}{l}\overline{\widehat{N}} \\
\stackrel{0}{0}\end{array}$ & $\begin{array}{l}\text { 守 } \\
\text { ñ }\end{array}$ & $\frac{n}{\frac{n}{n}} \frac{1}{0}$ & 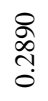 & $\begin{array}{l}\text { त्ठे } \\
\text { है }\end{array}$ & 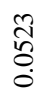 & $\frac{\text { oे }}{\stackrel{+}{0}}$ & $\begin{array}{l}\text { fo } \\
\text { +̦. } \\
\text {. }\end{array}$ & $\begin{array}{l}\stackrel{8}{0} \\
\stackrel{0}{0}\end{array}$ & $\begin{array}{l}\text { లn } \\
\text { ڤn } \\
\stackrel{0}{0}\end{array}$ & $\begin{array}{l}\text { ț } \\
\text { } \\
0\end{array}$ & $\begin{array}{l}\stackrel{0}{0} \\
\infty \\
\stackrel{0}{0}\end{array}$ & $\frac{\stackrel{2}{+}}{\stackrel{0}{0}}$ & $\begin{array}{l}\hat{0} \\
\text { ?] } \\
0\end{array}$ & $\begin{array}{l}0 \\
\stackrel{\circ}{0} \\
\stackrel{0}{0}\end{array}$ & $\frac{\infty}{\frac{\infty}{0}}$ & 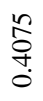 & 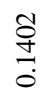 & $\begin{array}{l}\stackrel{n}{\tilde{n}} \\
\stackrel{0}{0}\end{array}$ & $\begin{array}{l}\hat{n} \\
\delta \\
+ \\
0\end{array}$ \\
\hline " & 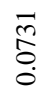 & $\frac{n}{\frac{n}{6}}$ & 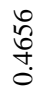 & 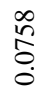 & $\begin{array}{l}\stackrel{2}{\infty} \\
\stackrel{\rho}{0}\end{array}$ & $\begin{array}{l}\bar{\sigma} \\
\stackrel{\infty}{+} \\
\stackrel{0}{0}\end{array}$ & $\begin{array}{l}\stackrel{0}{\infty} \\
\stackrel{\infty}{0} \\
\stackrel{0}{0}\end{array}$ & 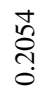 & $\begin{array}{l}\text { Oे } \\
\stackrel{+}{+} \\
\dot{0}\end{array}$ & 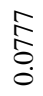 & $\frac{\stackrel{g}{\sigma}}{\stackrel{0}{0}}$ & $\frac{\mathbb{8}}{\stackrel{+}{+}}$ & $\begin{array}{l}8 \\
8 \\
0 \\
0\end{array}$ & $\begin{array}{l}\stackrel{P}{+} \\
\stackrel{0}{0}\end{array}$ & $\frac{0}{n}$ & $\frac{\Delta}{\stackrel{D}{J}}$ & $\begin{array}{l}\stackrel{0}{0} \\
\frac{\infty}{0} \\
\end{array}$ & 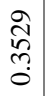 & $\begin{array}{l}\text { 㟧 } \\
\stackrel{0}{0}\end{array}$ & 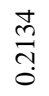 & $\begin{array}{l}\text { నิ } \\
\text { సె }\end{array}$ & 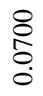 & $\frac{\infty}{\infty}$ & $\frac{\tilde{I}}{\vec{t}}$ \\
\hline $\begin{array}{l}0 \\
\text { 言 }\end{array}$ & $\begin{array}{l}\stackrel{0}{0} \\
0 \\
0\end{array}$ & $\begin{array}{l}\stackrel{ \pm}{\mathbb{N}} \\
\stackrel{0}{0}\end{array}$ & $\begin{array}{l}n \\
\frac{n}{n} \\
n \\
0\end{array}$ & $\begin{array}{l}\hat{n} \\
\overrightarrow{0}\end{array}$ & 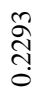 & $\begin{array}{l}\bar{\infty} \\
\text { N } \\
\text { ? }\end{array}$ & $\stackrel{\curvearrowright}{=}$ & ๙ֶ. & $\begin{array}{l}\hat{0} \\
\text { ñ } \\
0\end{array}$ & $\begin{array}{l}n \\
0 \\
0 \\
0\end{array}$ & 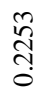 & 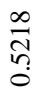 & \begin{tabular}{l}
$\stackrel{8}{0}$ \\
\hdashline \\
\end{tabular} & $\begin{array}{l}\hat{\sigma} \\
\stackrel{0}{0} \\
\stackrel{0}{0}\end{array}$ & $\frac{\stackrel{\circ}{\circ}}{\stackrel{\circ}{0}}$ & $\begin{array}{l}\stackrel{8}{8} \\
\stackrel{8}{0}\end{array}$ & $\begin{array}{l}\stackrel{8}{0} \\
\text { O̦ } \\
\stackrel{0}{0}\end{array}$ & $\begin{array}{l}0 \\
\stackrel{0}{N} \\
\stackrel{0}{0}\end{array}$ & $\frac{+}{\stackrel{+}{2}}$ & $\frac{\stackrel{t}{2}}{\stackrel{2}{0}}$ & $\begin{array}{l}\text { Jे } \\
\text { ஸे }\end{array}$ & $\begin{array}{l}\stackrel{\partial}{0} \\
\stackrel{0}{0}\end{array}$ & $\frac{\stackrel{\circ}{2}}{\stackrel{0}{0}}$ & 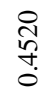 \\
\hline 言 & $\begin{array}{l}\mathscr{0} \\
\stackrel{0}{0} \\
0\end{array}$ & $\frac{\partial}{\frac{\sigma}{0}}$ & $\begin{array}{l}\text { 它 } \\
\text { f. }\end{array}$ & $\begin{array}{l}\hat{\sigma} \\
\text { 응 }\end{array}$ & $\frac{\hat{\infty}}{\stackrel{0}{0}}$ & $\begin{array}{l}\stackrel{n}{+} \\
\stackrel{f}{0}\end{array}$ & $\frac{\sqrt{n}}{0}$ & $\begin{array}{l}\infty \\
\stackrel{\overbrace{}}{0} \\
\stackrel{n}{0}\end{array}$ & స్ & $\begin{array}{l}\frac{n}{0} \\
0 \\
0\end{array}$ & $\frac{\tilde{n}}{\ddot{0}}$ & \begin{tabular}{l} 
\&े \\
ț \\
\multirow{0}{0}{}
\end{tabular} & \begin{tabular}{l}
8 \\
8 \\
\hdashline \\
0
\end{tabular} & $\frac{\text { O+ }}{0}$ & $\frac{N}{\stackrel{\infty}{I}}$ & $\begin{array}{l}\stackrel{0}{0} \\
\stackrel{8}{0} \\
\stackrel{0}{0}\end{array}$ & $\frac{\mathfrak{n}}{\stackrel{0}{0}}$ & 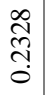 & $\begin{array}{l}\stackrel{8}{8} \\
\stackrel{0}{0}\end{array}$ & $\begin{array}{l}\stackrel{0}{0} \\
\text { Oִ. } \\
\stackrel{0}{0}\end{array}$ & 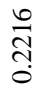 & $\begin{array}{l}F \\
\text { a } \\
0\end{array}$ & $\frac{8}{6}$ & \begin{tabular}{l}
$\infty$ \\
\multirow{\delta}{0}{} \\
+ \\
0
\end{tabular} \\
\hline 訔 & $\begin{array}{l}\stackrel{8}{0} \\
\stackrel{0}{0}\end{array}$ & 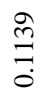 & $\begin{array}{l}\stackrel{0}{0} \\
\text { ?n} \\
\text { ?. }\end{array}$ & $\stackrel{n}{\stackrel{n}{0}} \frac{0}{0}$ & $\begin{array}{l}\infty \\
\stackrel{\infty}{=} \\
\end{array}$ & 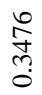 & $\frac{N}{\infty}$ & $\frac{\widetilde{N}}{\stackrel{\Xi}{0}}$ & 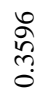 & $\frac{\Delta}{\stackrel{J}{0}}$ & 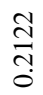 & 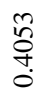 & $\begin{array}{l}8 \\
8 \\
\circ \\
\circ\end{array}$ & $\begin{array}{l}\bar{a} \\
\stackrel{\sigma}{0}\end{array}$ & $\begin{array}{l}\frac{1}{f} \\
\stackrel{0}{0} \\
0\end{array}$ & ஜ̊ & 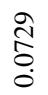 & 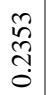 & $\begin{array}{l} \pm \\
\stackrel{0}{0} \\
0 \\
0\end{array}$ & $\begin{array}{l}\text { I } \\
\infty \\
\stackrel{0}{0} \\
\stackrel{0}{0}\end{array}$ & 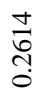 & $\begin{array}{l}\tilde{0} \\
0 \\
0 \\
0\end{array}$ & $\begin{array}{l}\text { గై } \\
\stackrel{0}{0}\end{array}$ & 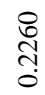 \\
\hline
\end{tabular}

